\title{
The transition to farming in Southeast Europe: perspectives from pottery
}

\author{
Mihael Budja \\ Department of Archaeology, University of Ljubljana, Slovenia \\ miha.budja@uni-lj.si
}

\begin{abstract}
The transition to farming in the Balkans, Ionia and the Adriatic is discussed as the palimpsest relates to artefact assemblages, subsistence and archaeogenetic data. It is argued that it marks a dispersed and selective route towards farming adaptation in the regions. The incoming neareastern lineages and the difference in values for the Balkans ( 20\%) and Mediterranean coastal $(\sim 10 \%)$ area are linked to a network of the circulation of goods and people over long distances which was established after the incipient adoption of farming.
\end{abstract}

IZVLEČEK - V članku analiziramo process neolitizacije na Balkanu ter vzhodni jadranski in jonski obali. Prehod $h$ kmetovanju obravnavamo kot palimpsest (zapisov) povezanih $z$ oblikovanjem artefaktnih zbirov, paleogospodarstev in arheogenetskih sekvenc. Zadnje povezujemo z vzpostavitvijo sistema menjave blagá in ljudi na Balkanu in Mediteranu.

KEY WORDS - transition to farming; archeogenetic data; pottery

\section{INTRODUCTION}

After many years of modern investigation the transition from mainly hunter-gatherer Mesolithic to predominantly farming Neolithic societies still remains embedded in the context of a succession of periods, a linear evolution and cultural development, which linked mobile hunter-gatherer groups with the Mesolithic, and sedentary farmers with the Neolithic. The dominant model depicted hunter-gatherer social systems as rigid patrilocal, exogamous and territorial band organizations, and related this to a scarcity of resources and the importance of hunting. Farming, on the other hand, would imply, at the first sight, different relations of production, with cultivation removing many of the risks and uncertainties of hunter-gathering, allowing accumulation, and thus making reciprocity far from desirable. Although it is broadly accepted that early farmers still made extensive use of hunted and gathered resources, it remains the paradigmatic view that the hunter-gatherer and early farming communities can be distinguished from one another in their forces of production, including the technological sets that they employed. It still maintains the premise that hunter-gatherer's (i.e. late Mesolithic) and farmer's (i.e. early Neolithic) artefact sets, being deposited in cave sites in southeast Europe and the Mediterranean mainly, by definition belong to different (mutually exclusive) stratigraphic, chronological and cultural contexts.

The interpretation of the transition to farming in Europe is linked to the assumption that farming emerged in the context of four critical innovations - domestic plants and animals, polished stone tools, and ceramics. The typological determinations and spatially restricted distributions of different pottery types (the normative identification) supposed to correlate with the genesis of Early Neolithic cultures on the regional level on the one hand and, the migration of farmers bringing in all the concomitant knowledge and skills of farming (in accordance with Childean cultural and revolutionary approaches) on the other. Several mutually exclusive regional pottery distribu- 
tions - the "Balkan-Anatolian complex of painted pottery" in Southeast Europe, the "Cardium-impresso Pottery Culture" in Mediterranean and the "Linear Pottery Culture" in Central and West Europe - were used to objectify the gradual colonisation of Europe. The first and the second have been recognized as the "secondary centres of the neolithisation of Europe", that most direct link to the cultural traditions of Asia Minor. The rate of spread of newcomers across Europe, and the colonisation of the continent, was objectified by a suggestive pattern of hundreds of radiocarbon dates relating to the earliest Neolithic settlement strata comprising pottery and domesticates. When those dates are plotted on the continental map, a south-east to north-west gradient becomes evident, suggesting that it may have taken about 2500 years for the agricultural frontier to reach the ends of the continent and to complete the process of the transition to farming in Europe (Clark 1965.58-73; Lüning 1988(1991).29-30; Breunig 1987; Parzinger 1993; Müller 1994; Ammerman, Cavalli-Sforza 1984.58-62, Fig. 4.5).

\section{INTERPRETATIVE BACKGROUNDS}

Although it is broadly accepted that the process of neolithisation of Europe was related exclusively to the change from food collection to food production, it still remains a controversial question whether this change in the palaeoeconomy was the consequence of cultural diffusion or demic expansion. The first hypothesises that it was farming that was diffused and adopted by local foragers. The latter states that there were farmers, and their language radiated from the Middle East toward Europe, Central and South Asia, and to some extent North Africa. Perhaps the most popular recent interpretation is based on the model of an "isochronic line of agricultural expansion in Europe" (Ammerman, Cavalli-Sforza 1984.58-62, Fig. 4.5; Cavalli-Sforza and CavalliSforza 1995; Cavalli-Sforza 1996; Cavalli-Sforza, Menozzi, Piazza 1993.639-646). Using the concepts of "demic expansion", "wave of advance" and "agricultural frontier zone" they suggest a slow expansion of people into Europe driven by population growth resulting from agricultural surpluses, and either the displacement or absorption of the less numerous hunter-gatherer populations. Thus the rate of advance of agriculture into Europe is held to be compatible with the estimation that the farmers spread, hypothesising fertility rates and mobility of early farmers comparable to those observed in ethnographically similar situations. In correspondence with the relocation of the agricultural frontier, shifting at a rate of $1 \mathrm{~km}$ per year across the continent, demic expansion is supposed to have had a dramatic effect on the European gene pool. The most important consequence is that the major component of the modern European gene pool derives from NearEastern Neolithic farmers rather than indigenous Mesolithic foragers. In other words, the Eurasian neolithisation process in the period $9500-5500 \mathrm{BP}$ was exclusively the domain of Near-Eastern farmers who were allowed to plant their genes and farming practices across Europe, Central and South Asia, and preserve their ethnic, cultural and social identity.

It is important to note here that the evidence provided by the sites where the elements of a farming economy in the contexts of typologically determined "Late Mesolithic (culture)" is rarely discussed, whether because of taphonomic filters operating in a framework of unsystematic and inconsistent research procedures and interpretative postulates which maintain that Mesolithic stone tool assemblages and elements of the "Neolithic package" are culturally, chronologically and spatially mutually exclusive, or because of prejudices toward hunter-gatherers in general and Mesolithic peoples in particular. What I would like to suggest here is that it is no longer sufficient to use the modified "Three-Age" typological paradigm as a heuristic device to direct our interpretational modelling or to minimize the social context of the agricultural transition by such claims as that "...local groups also hunted goats, probably derived from coastal herders, before the former adopted domestication..." (Chapman \& Müller 1990.132).

A recent revival of interest in the transition to farming has brought about the understanding that agriculture developed independently in several areas of the world and that clear-cut shifts from dependence on hunting, fishing and gathering to dependence on agriculture depended on a number of particular conjunctions of circumstances in particular places at particular times (Harris 19966.553, 557), and it de facto remains a problem to recognise the processes by which agriculture and pastoralism became established throughout Eurasia.

It is important, however, to stress the significance of pre-Neolithic adaptations for the development or adoption of incipient agriculture, since small-scale cultivation of (mainly) wild plants and animals is practised by indigenous foragers in the context of a "continuum of people-plant-animal interaction" (Harris 1989.11-26; 1996a.1-9). Therefore, it is a choice 
of manipulating resources rather than the actual fact of substituting wild resources with domesticates. It was suggested that instead of conceiving the transition from hunting and gathering to herding or cultivation as an evolutionary progression from one distinct type of society to another we have to be aware of the usefulness of treating hunting and gathering, herding and cultivation as alternative strategies which are, separately or in combination, appropriate to particular social or natural environments (Layton, Foley and Williams 1991.255-274; Hawkes, O'Connell 1992.63-65). It is useful to remember that the questions of "when", "where", "why" and "who" (Halstead 1996.296-309) are still of basic interest in the "late Mesolithic and early Neolithic" palimpsests in Southeast Europe and the Mediterranean. Was "Neolithic man ... the first human producer", and was there "no other before him", as Cauvin (2000.207) recently claimed? Was the origin of Neolithic plant and animal packages exclusively in the Near East, which then spread throughout Anatolia and Europe (Zohary and Hopf 2000)? Was the Mesolithic population sparse throughout Europe (Meiklejohn et al. 1997; Jackes et al. 1997) and was it really genetically replaced by different mechanisms of population diffusion that correlate with agro-pastoral dispersals (Zvelebil 2000.57-79)? And finally, the question that might have been asked in the traditional interpretative contexts from the very beginning: was it "cardial" and "monochrome" pottery that marked the initial Neolithic cultures in the Balkans and Mediterranean, or does it, in fact, represent a widely distributed set of shapes and motifs, symbols which were recognized and used by members of different groups and served to signify specific social interactions, power relations and exchange networks (as containers for foods) within and between the late hunter-gatherer and early farming communities?

\section{THE TRANSITION TO FARMING IN EUROPE AND THE GENETIC PALIMPSEST}

We have already mentioned that perhaps the most popular interpretation recently is represented in the work of Ammerman and Cavalli-Sforza. They introduce into archaeology the principle of synthetic genetic maps - geographical maps of isopleths (lines of equal value) of principal component values, calculated as optimised linear functions of all available gene frequencies of modern Eurasian populations (Menozzi, Piazza, Cavalli-Sforza 1978.786-792). Seven principal components were listed, while the first three are recognized as the most significant and are rather arbitrarily linked with specific historical events and processes. There is no doubt, however, that "a principal components analysis represents a palimpsest of all the processes which have taken place, from the earliest human settlement to the present time." (Renfrew 2000.5).

Ammerman and Cavalli-Sforza based the interpretation of the transition to farming in Europe on analyses of correlations of "contour maps" for the first principal component from 95 gene frequencies with the southeast (Levant) - northwest (Europe) gradient and maps of the "latest" Mesolithic occupation and the "spread of early farming to Europe" which is an updated version of the distribution of radiocarbon dated early Neolithic sites published by Clark in 1965 (Ammerman, Cavalli-Sforza 1984. Figs. 4.5-6, Fig. 6.10; Cavalli-Sforza 1996.61, Fig. 4.1a). They believe that the "extraordinarily high" resemblance of the maps demonstrates:

- there was "no prolonged chronological overlap between Mesolithic occupation and the onset of early farming" in Europe (Ammerman, CavalliSforza 1984.60) and,

- the pattern of temporal and spatial distribution of early Neolithic settlements corresponds well with the contour map of the distribution of the first principal component of gene frequencies in modern European populations (Cavalli-Sforza 1996.53).

However, the frontier lines of the 500 year temporal intervals of spatial distribution of early Neolithic sites that run parallel to one another over much of Europe were determined as "an isochronic line of agricultural expansion in Europe" (Ammerman, Cavalli-Sforza 1984.Fig. 4.5; Sokal, Oden, Wilson 1991. Fig. 1; Cavalli-Sforza, Menozzi, Piazza 1993.Fig. 2a; Cavalli-Sforza 1996.Fig.4.1). In accordance with "the wave of advance model" they hypothesised the increased population densities within the agricultural frontier zones, causing demic expansion into new territory at an average rate of $1 \mathrm{~km}$ per year and a diffusive gene flow between the Neolithic farmers and Mesolithic hunter-gatherers. In consequence, there would be less expectation of continuity between the two, and the contribution of the latter to the subsequent development of the genetic and cultural history of Europe is supposed to be insignificant.

Although the archaeological data cannot directly address the question of demic expansion and genetic replacement, the estimation of the dynamics at the 
agricultural frontier is directly linked to the identification of the distribution of Early Neolithic sites in "time and space". It is hypothesised that there is a relationship between the distribution and density of archaeological sites and the distribution and density of human populations in the selected regions. An old idea that was revived recently holds that, because of an almost total lack of evidence of Mesolithic sites in both Central and Southeast Europe and the Iberian Peninsula, the Mesolithic population must have been very sparse and, in consequence, this would have allowed farmers to expand and colonise the regions rapidly (Pinhasi, Foley, Mirazón 2000.50, 54; see also Trinhgam 1968.46-53, 67. Fig. 7). It was already evident that the present distribution of (late) Mesolithic (early) Neolithic was very much affected by the processes (long-term and catastrophic) that restructured the geomorphology and reshaped the relief of the regions in the Holocene. In plotting sites on a general map of Eurasia and in hypothesising a spatial discontinuity between Mesolithic and Neolithic settlements, we have to take into consideration the fact that the patterns available to research are the various outcomes of consecutive cycles of alluvation, erosion, and sedimentation of valleys and the rise in Mediterranean, Marmara and Adriatic sea-levels (Chapman 1989; 1994; van Andel, Gallis and Toufexis 1995.131; Lambeck 1996. 588-611; Ryan et al. 1997.119-126; Okay et al. 1999. 129; see Kotsakis in this volume). With this in mind, I would argue that many coastal or inland riverside sites of the Mesolithic or, more importantly, many short-term Early Neolithic sites still remain unavailable, buried under alluvium or covered by sea.

Some further thoughts on the restrictions connected with the selection and formation of artefact sets should also be considered. The distinction between Neolithic and Mesolithic sites was based on general typological categorizations, which were used to objectify hunter-gatherers and farmers "cultural" sequences. This objectification maintains the paradigmatic perception that farming practices could only be embedded in Neolithic "cultural" contexts (Zithão 1993.47-49; 1997.19-42; Budja 1996a.61-76). From this point of view it is impossible to ignore the fact that an analysis of spatial distribution of early Neolithic settlements may not reflect the actual diffusion of farming practices and changes in subsistence strategies. However, the story was recorded in the genetic pattern produced by DNA from Y (male) chromosomes (Cavalli-Sforza and Minch 1997.274251; Sykes \& Renfrew 2000.13-15). The map for the First Principal Component, representing 28.1\% of the modern genetic variance of Europe, showed a clear gradual distribution in values between the Near East and Northwest Europe; however, it was recently realised that:

- a principal components analysis is a palimpsest of all the processes that have taken part in the historical process it accounts for;

- a large part of the first principal component - the classic markers - may have been due to earlier gene flow processes and that the overall genetic impact of the Neolithic in Europe with a greater emphasis on is now being correlated to the initial colonization in the Palaeolithic and subsequent colonization episodes in the Mesolithic;

- the low proportion of variance associated with the first principal component for classical markers (28.1\%) indicates a minor input by the Neolithic newcomers and the great significance of the Mesolithic contribution to later European prehistory (Renfrew 2000.5, 9; Sykes \& Renfrew 2000.17; Sykes 2000.26).

A much more precise story is found in the pattern of mitochondrial DNA genetic gradients, giving us the female $(\mathrm{X})$ picture. Before we continue, a word about the human genome - the collective name for the entire DNA in each cell. It is organized into separate volumes - chromosomes deposited in the cell nucleus. There are twenty-four different chromosomes in the human genome, but we have two sets of most of them, one from each parent. Twenty-two of them are known as autosomes, the other two $\mathrm{X}$ and $\mathrm{Y}$ chromosomes determining sex. Males have both $\mathrm{X}$ and Y-chromosomes, but females have a pair of Xchromosomes only. The human genome contains one other, very special piece of DNA - mitochondrial (mt) DNA - embedded in the cell cytoplasm. Unlike nuclear DNA, it is inherited from one parent only, the mother. This means that at any time in the past only one woman alive at that time was the maternal and hence the mitochondrial DNA ancestor of a particular person, which is definitely not the case with nuclear DNA, where the number of potential nuclear ancestors doubles at every generation (Sykes \& Renfrew 2000.14). So far, in archeogenetic studies relating to the origins of the Neolithic and the agricultural transition in Europe, the DNA as it survives in the genes of living people has been used in sampling, sequencing, geographically patterning and interpreting events and processes in the remote past in spite of critical limitations. The methodological topics have already been discussed (Richards et al. 2000.1251-1276). But as a non-geneticist I would suggest we remember that the reconstruction of ge- 
netic history and its explanation through migration or demic diffusion relates to the survivors, existing descent lines, whether represented in male (Y chromosomes) or female (mtDNA) markers and, that those numerous lineages which became extinct are by definition not recorded in the living record - the extant genetic palimpsest (Richards et al. 1996.185198; Sykes \& Renfrew 2000.16).

However, the "founder analysis" of mitochondrial DNA seems to be more reliable in identification and dating of migrations into new territory and in the evaluation of the suggested Neolithic demic diffusion and population replacement. The analysis confirmed the southeast-northwest spatial gradient on the one hand, but showed the low values obtained for the demic component of the Neolithic expansions on the other. It was suggested that "...most of the modern European mtDNA landscape was formed neither in Early Upper Palaeolithic colonization ... not as a result of demic diffusion from the Near East ... but rather in Late glacial re-expansions within Europe itself." (Richards \& Macaulay 2000.148). Based on the results of the founder analysis of mtDNA, Richards et al conclude that $<10 \%$ of extant lineages date back to the first colonization of Europe by anatomically modern humans, and that on the order of $10-20 \%$ arrived during the Neolithic, but most of the other lineages "seem most likely to have arrived during the Middle Upper Palaeolithic and to have expanded during the Late Upper Palaeolithic" (Richards et al. 2000.1272). It is interesting that Neolithic contributions to extant mtDNA evidently vary regionally and that the incoming lineages, at least on the maternal side, were in the minority, in comparison with indigenous Mesolithic lineages, even in those regions where centres of secondary neolithisation and the pioneer colonization of uninhabited areas have been suggested. Regional analysis shows the Neolithic contribution - the incoming lineages with the values of $\sim 20 \%$ for Southeast, Central, Northwest and Northeast Europe. In the Mediterranean coastal area it is even lower than $\sim 10 \%$, similar to that in Scandinavia (Richards et al. 2000. 1271). On the explanatory level, recognizing the major sig- nificance of the indigenous Mesolithic lineages, they also suggest that:

- acculturation occurred principally in Southeast Europe;

- the expansion of the LBK (Linearbankeramik) cultural complex through Central Europe did indeed include a "substantial demic component", which in consequence means that there was a "considerable replacement" of population;

- the transition to farming in the Mediterranean and Scandinavia was very late and "the impact of newcomers likely very slight" (Richards et al. 2000.1271).

We have to note some salient points in this interpretative context concerning the results of recently available genetic studies of domestication of emmer wheat that "appears to have expanded from the Near East on two occasions, correlating closely with the observation by Richards et al. (1996)" of the two incoming and chronologically distinctive Neolithic lineages (Allaby 2000.323). It is broadly accepted that wild emmer, tertraploid wheat (Triticum dicocoides) is endemic to the Near Eastern "arc" where its domestication could only have taken place and Neolithic agriculture have originated. It was suggested also that genetic comparisons between the founder crops and their wild progenitors suggest that the wild ancestors of most of them (except for barley) were introduced into cultivation only once and at only one location (Zohary \& Hopf 2000.243). However, the results of the molecular phylogenetic studies of modern plants suggest that emmer wheat may have been domesticated more than once, and

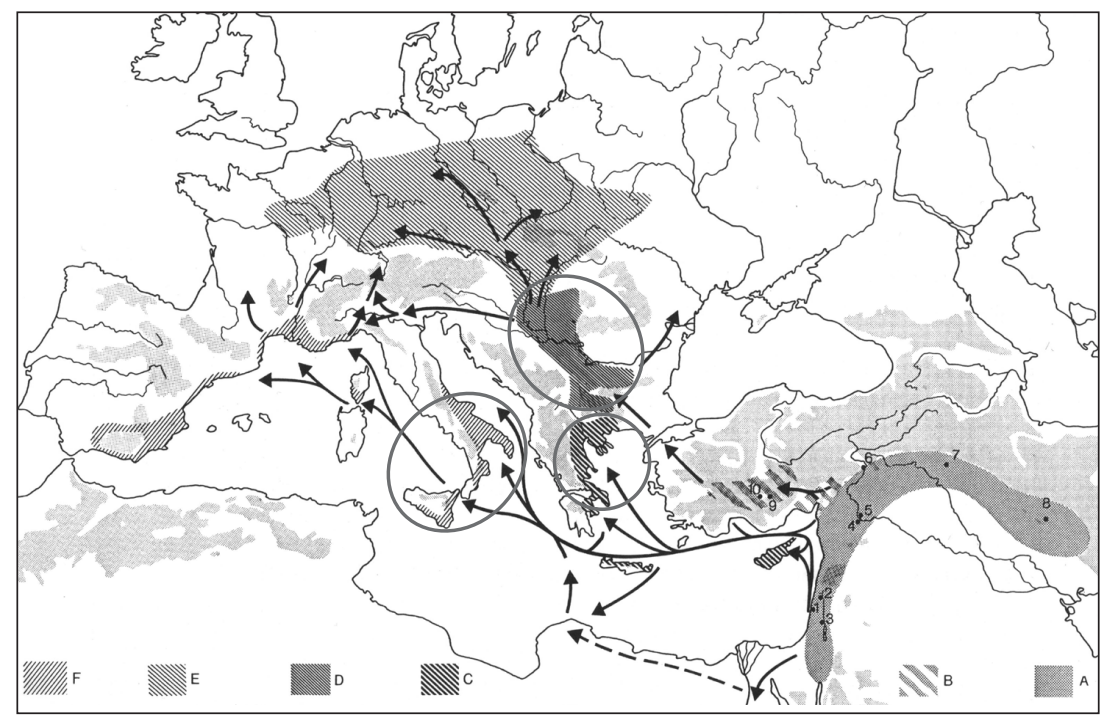

Fig. 1. The Neolithisation of Europe. Primary (Thessaly) and secondary (Balkans and western Adriatic coast) centres of colonisation (after Lüning 1988(1991).Abb.1). 
that hexaploid wheats (e.g. Triticum spelta and Triticum aestivum), which arose from a hybridisation of emmer and the wild grass Aegilops squarrosa, have multiple origins (Brown 1999.89-98).

Genetically-driven explanations are usually used to argue that the biogeography of plant domesticates can indicate "expanding populations" or a "record of human movement" (Harris 19966.569; Allaby 2000. 321 ), although it is well known that genetic analysis is unable to determine whether the movement of a domesticate from one location to another was due to its being carried by group of migrating humans or if it resulted from trade between two static communities (Brown 1999.89-98). Discussing the archaeological data in the western Mediterranean we have already pointed out that no direct or indirect evidence of cereal agriculture has yet been found that could have correlated with the hypothesised initial colonisation and, with all due respect to the motto absence of evidence is not evidence of absence, on the Iberian Peninsula crop-husbandry appeared a few hundred years later than animal-husbandry ( $B u$ dja 1999.122-128; cfr. Zilhão 1997.23-26; Bernabeu Aubán 1997.11-12). In the eastern Mediterranean, in contrast, on the tip of the Balkan Peninsula in the Grevena region, the present-day habitats for wild einkorn exist (Zamanis et al. 1988). It is perhaps no coincidence that among the archaeobotanical remains collected from the Mesolithic deposits in the nearby Theopetra cave wild einkorn wheat (Tri- ticum boeoticum) has been reported (Kyparissi-Apostolika 2000.137). But the Balkans region seems to remain excluded as an area of primary domestication of wild einkorn (Heun et al. 1997.1312-1314; 1998.65-69; Zohary \& Hopf 2000.36-42, 243; Gopher et al. in this volume). It is worth mentioning that einkorn wheat "appears to be less frequent" than two other founder cereals (emmer and barley) in the Levantine Neolithic, which is certainly not the case in the Balkans where much richer remains of einkorn wheat are available. Einkorn prevails over emmer wheat in "the frequency of pure hoards", retaining its principal role throughout the Neolithic and even later periods (Zohary \& Hopf 2000. 38-39). It has been demonstrated in Southeast Europe that the evident impact of the first farmers on vege- tation was neither on a landscape scale nor in the form of a time-transgressive wave of forest clearance (Willis \& Benett 1994.326-330; Willis 1995. 9-24). But small-scale forest clearance, burning, and coppicing, however, predate the earliest Neolithic sites in the regions (Andric, in this volume). It is my belief that the application of the concept of a "continuum of people and plant interaction" such as that mentioned above in the context of pre-Neolithic adaptations for the development or adoption of incipient agriculture should definitely be taken into consideration in the Balkans.

An analysis of strontium isotope deposited in human skeletal material confirmed recently the human migration in the context of the genesis of the LBK cultural complex and the dispersion of agriculture in Central and West Europe. The strontium isotope in human teeth and bones provides separate geochemical markers of the place of birth and the place of death. This means that a difference in the isotope ratio provided by the two samples of the same individual indicates a change in residence during the lifetime (Price at al. 1994.315-330). Sampling the middle and the late LBK cemeteries in the Upper Rhine Valley, Price and his group found proof of "substantial migration" (Price et al. 2001.601). The results in the middle Neolithic cemetery in Flombron indicate a high proportion of migrants (64\%) of both sexes had moved there from some distance away. However, a substantially different pattern ap-

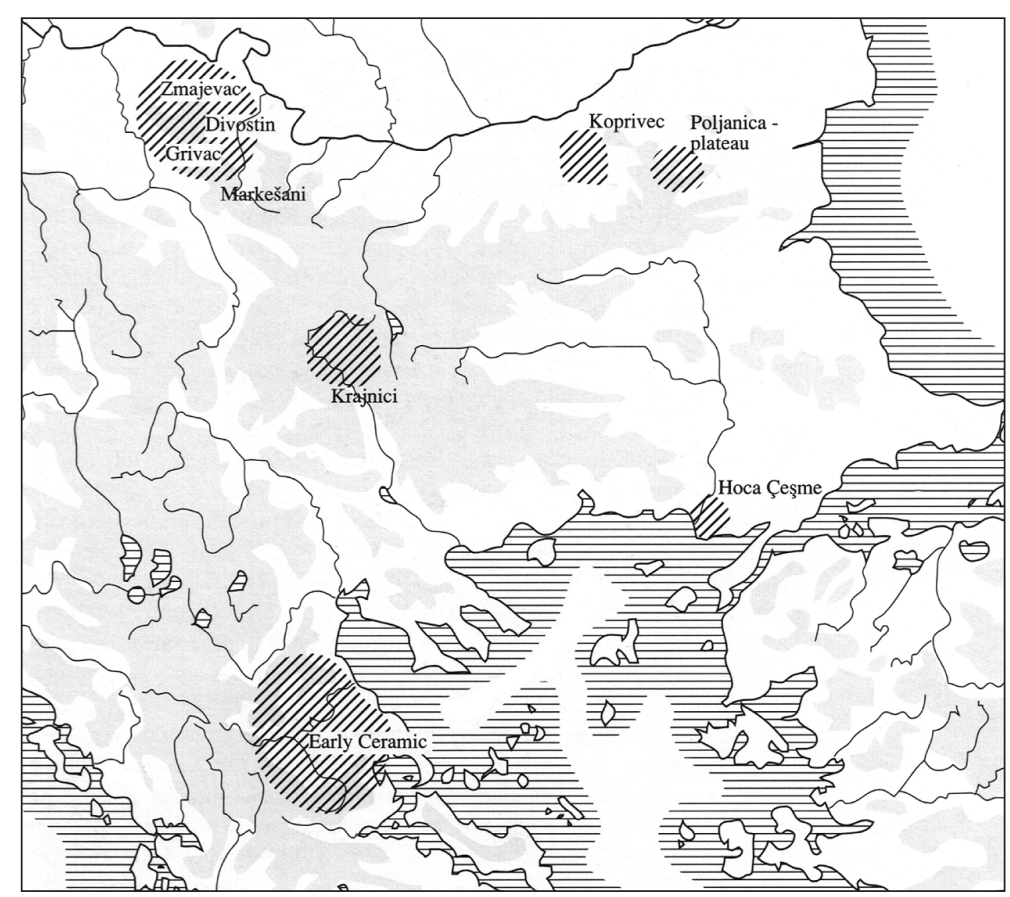

Fig. 2. "Centres of the Balkan Monochrome Neolithic" (after Vajsov 1998. Map 1). 
peared in a late Neolithic cemetery in Schwetzingen. A smaller proportion (33\%) of the sampled population were migrants, the majority of them younger women. It was hypothesised in this case that migration may have primarily been a result of residential changes upon marriage, and that these females may have come from neighbouring farming areas or across the agricultural frontier zone from hunter-gatherer communities (Price et al. 2001.589-601). Migration and frontier mobility are linked, however, to the pattern of temporal and spatial distribution of the earliest LBK settlements, and it was suggested that the sequence from $5700 \mathrm{BC}$ to $5500 \mathrm{BC}$ of the earliest radiocarbon dates within the normative determination of the earliest LBK cultural phase, demonstrates a rapid expansion of farming communities over hundreds of kilometres from the central Danube and Carpathian basin to the Rhine in the west. Price et al hypothesised on the base of the high proportion of migrants and the appearance of the spondylus shell (artefacts), originating in the Aegean, in Flombron graves, that the "local individuals in the cemetery" represent the descendants of the original farming population of the earliest LBK who initially migrated from the southeast and colonised the central part of Europe. Even more, they believe that the correlation of the strontium isotope results and the orientation of sampled burials in Flombron indicate the westward trend of population movements (Price at al. 2001.600-601). However, in my opinion, there are uncertainties regarding the understanding and interpretation of strontium evidence. First of all, the local geology is an essential ingredient in understanding variation in strontium isotopes, which means that the identification of human mobility between the two supposed, economic or social entities is being speculated on the base of geochemical variation in the selected (micro) regions. And, it also means that the short-distance va- riation in the regional geomorphology, embedded in strontium isotope signal could be interpreted as the long-distance cross regional migration. However, Price at al. "suspect" that the geochemicaly distinct uplands on either side of Rhine were occupied by Mesolithic foragers and that the river valley was colonized and settled by the lowland farming communities. Individuals from these groups who may have migrated to lowland farming settlement should be identifiable by local strontium isotope signal (0. c. 597-598). Finally, some evidence for pre-Neolithic cultivation and for small-scale animal husbandry and horticulture in the region became available recently (Erny-Rodmann et al. 1997.27-56; Price et al. 2001. cfr. Schweizer 2000).

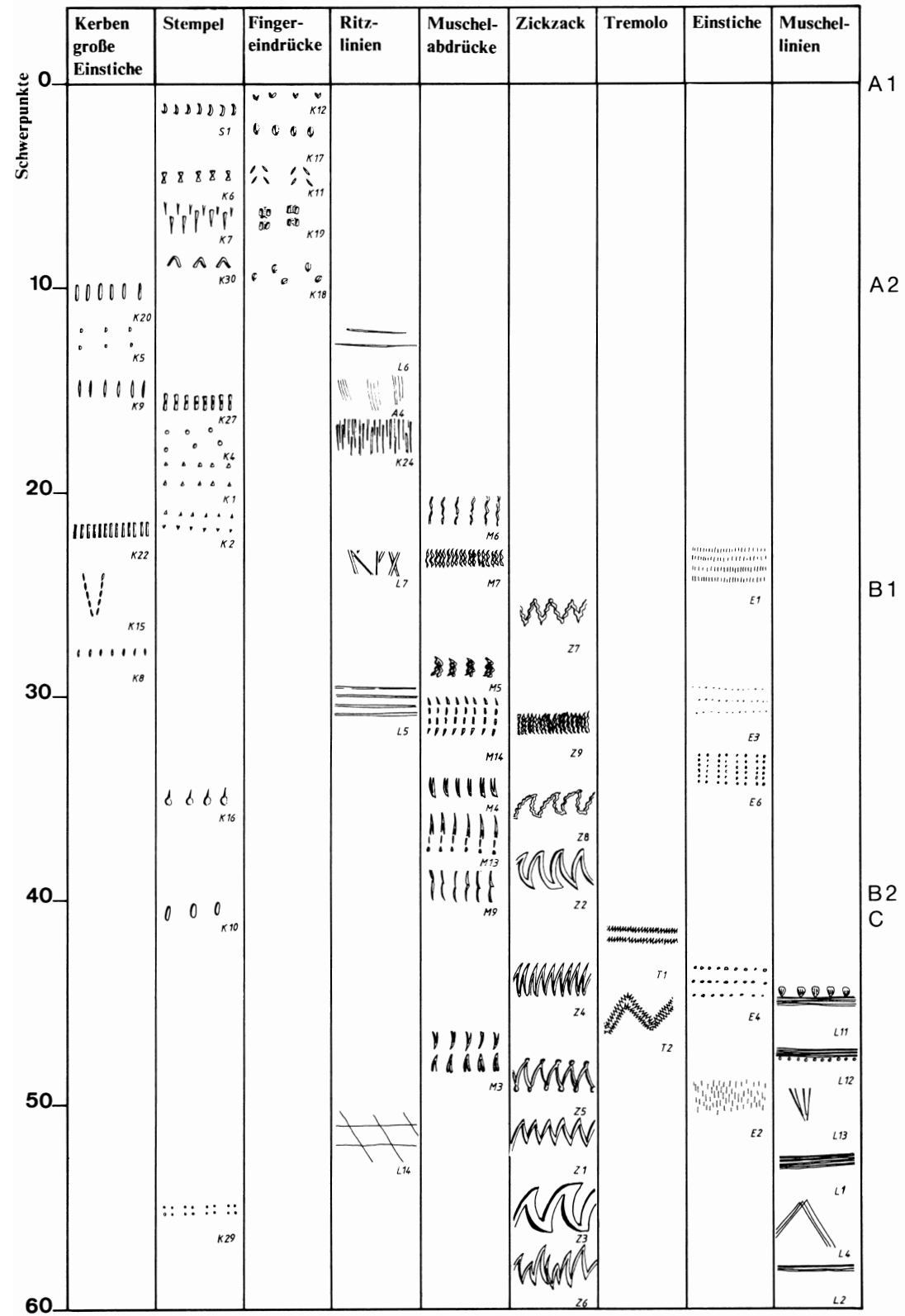

Fig. 3. Early Neolithic ornamental sequence in Eastern Adriatic (after Müller 1991.Abb. 8). 
Although aware of our own incomplete understanding of methodological approaches involved, as well as of the broader interpretative implications of human lineage patterns, I would point suggest the results of the mtDNA analysis has revised the interpretation of the transition to farming and the neolithisation of Europe. It is broadly accepted that the overall genetic impact now being placed on Palaeolithic and Mesolithic events and neolithisation processes played a minor role in shaping the current European gene pool (Renfrew 2000; Sykes, Renfrew 2000; Sykes 2000; Richards et al. 2000; Richards \& Macaulay 2000). It is our belief, however, that the dispersal of farming was embedded in the existing, preNeolithic social contexts, economic parameters, patterns of mobility, and the palaeoenvironmental conditions of each geographical entity in Southeast Europe. With the growing body of data from different (micro)regions, it has become apparent that the introduction of farming to Europe was not the monothetic consequence of the "wave of advance" and demic expansion as a mean of "an actual colonisation by real people (always without faces, gender, age, etc.)" as was, for example, ironically indicated Ruth Tringham recently (2000.31), but the clusters of "several related but different processes, spanning several millennia, and following distinctive regional and local trajectories" (Halstead 1996.306). It is worth noting that in order to examine the interactions of communities with different modes of subsistence (foraging and farming respectively), non-metric anatomical variants of the skull and post-cranial bones were examined on sites with the largest number of individuals buried, and where the coexistence of Mesolithic and Neolithic modes of subsistence in the region was demonstrated as having been over one thousand years (Voytek \& Tringham 1990.492-499; Radovanović 1996.39-43; Radovanović \& Voytek 1997.21). In view of a proposed porous frontier between Mesolithic and Neolithic cultures in the region (sensu Dennell 1985 and Zvelebil 1996), osteological material does not exhibit significant differences between Lepenski Vir Mesolithic and Balkan-Anatolian complex of Early Neolithic (Starčevo Culture). Furthermore, the data presented by Roksandić (2000.1-100) argue strongly against the wave of advance model that proposes the supplanting of local foragers by incoming farmers, even if the substitution is understood as partial and continuous.

\section{POTTERY IN THE CONTEXT OF THE NEOLITHI- SATION OF EUROPE: THE BALKANS AND THE ADRIATIC}

There is no doubt, however, that the pottery in most interpretative contexts was primarily used as a chronological and 'ethnic' marker in determining the genesis of Early Neolithic cultures at the regional level. In the ex oriente lux model its symbolic status and social role in farming societies in the Balkans and the Aegean have been limited to the identification of "indisputable typological similarities" with the cultural traditions of Asia Minor. Many authors have traced similarities between the Balkans and Anatolia, and the dependence of the former on the latter has never been questioned. The Aegean and the Balkans were hypothesised as recipients "of repeated waves of migrations from Anatolia and Syro-Cilicia in particular, as well as of cultural influence that came independently, or actual migrations" (Weinberg 1965. 308). On the other hand, the pottery was recognized as the "backbone of archaeology" and "the most obvious diagnostic element" in the context of a cultural continuum from east to west. Although at first it was "secondary rather than an indispensable element of the Neolithic", or of the food-producing economy, it nonetheless becomes predominant amongst all the finds from the moment that its use becomes widespread in an Early Neolithic stage" (Theocharis 1973.39). It is not surprising that the virtually paradigmatic status of spatially restricted distributions of selected pottery types and ornaments has been used to mark the boundaries of the primary and secondary centres of neolithisation, as well as the sequential colonization of Southeast Europe.

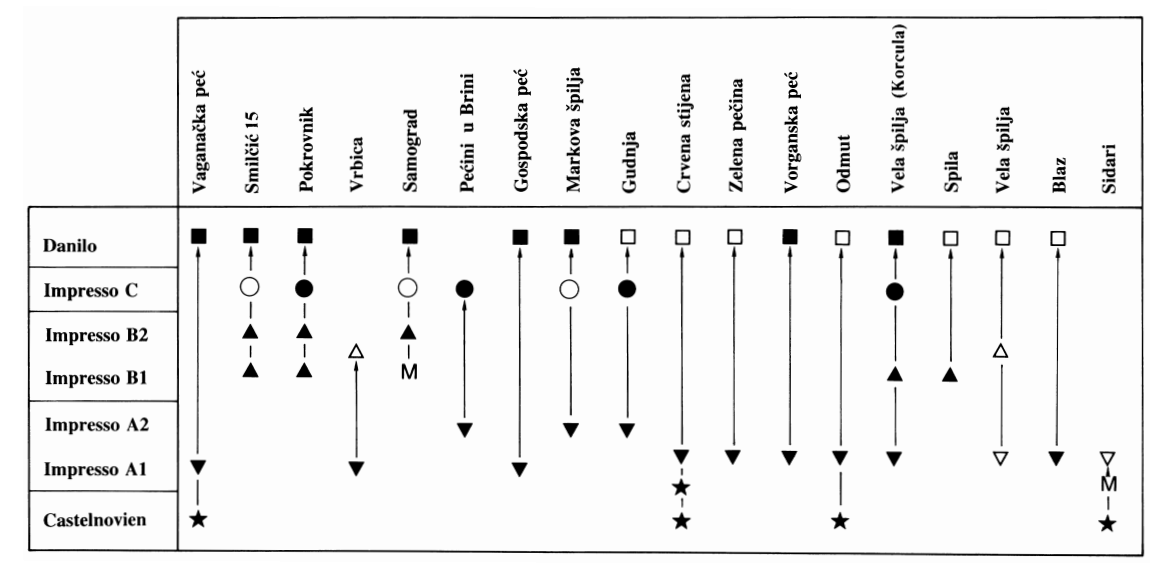

Fig 4. Early Neolithic sequence in Eastern Adriatic (after Müller 1994.Abb. 74). 
Contemplating the dawn of the Aegean and the Balkan Neolithic, Milojčić and Theocharis hypothesised an Early Neolithic relative chronological and cultural sequence of a "pre-ceramic", "monochrome" (Achilleion or EN I), "red-on white" painted pottery (Protosesklo or EN II) and "impresso" pottery (Presesklo/ Magulitca EN III) (Milojčić 1959.1-56; 1973a.248-251; Theocharis 1967; Breunig

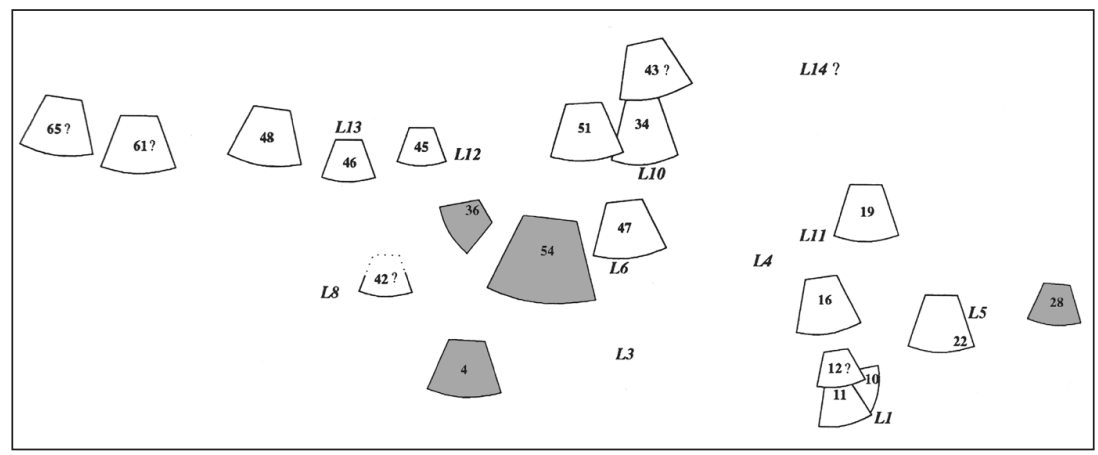

Fig. 5. Lepenski Vir I: Phase 2. A pots in houses 4, 28, 36 and 54, marked with shaded house plans (after Radovanović 1996; Garašanin \& Radovanović 2001.118-125).
1987.93-101; Müller 1991.333-340; 1994.205, 215-221; Parzinger 1993). Having correlated the Thessalian, Çatal Höyük and Haçilar sequences, they objectified a paradigmatic mirror chronological scheme equating the Aegean Early Neolithic towards "the short Neolithic" and Middle and Late Neolithic towards "the long Chalcolithic" periods in Asia Minor (Schachermeyr 1976.174-176). However, although stressing the contemporaneity, similarity and primitiveness of the earliest Thessalian and Çatal Höyük (East, levels XII-IX) monochrome pottery, Theocharis made the point that "... we do not believe that this primitive pottery was introduced from Asia Minor." (Theocharis 1967. 173).

It was hypothesising that the confinement of the region to be settled by Anatolian migrants first, the primary centre of neolithisation in Europe, correspond with the spatial distribution of settlements comprehending "pre-ceramic" and "monochrome" pottery layers in Thessaly. The common marker of the demic expansion, "a breakthrough of the elements of the Balkan-Anatolian complex of the Early Neolithic" towards the Danube and of the creation of secondary centres of neolithisation was determined by the distribution of pottery with white painted decoration. Moreover, in combination with impresso and barbotine pottery it is being used as the determinative element in correlating the Presesklo/ Magulitca and initial phases of Karanovo and Starčevo-Körös-Çris complexes. This made it possible to equate the initial phase of the Early Neolithic in the northern Balkans and Carpathian with its end in Thessaly and the formation of an agricultural frontier zone in the Danubian zone. In diffusionistic perspective the "indisputable typological similarities" of painted pottery distributed between Anatolia, Balkans and Carpathian is recognized as the constitutive "Anatolian" element of the Balkan-Anatolian complex, as well as an "ethnic" marker in the gene- sis of a koine among the first farmers in the Balkans and Anatolia (Milojcic 1952.313-318; 1956.208210; 1959.1-56; 1960.320-335; Nandris 1970.192213; Benac, Garašanin, Srejović 1979.27; Garašanin 1979.84-106; Garašanin, Radovanović 2001. 118-125; Nikolov 1987.8-19; 1990.63-69.Abb.7; 1998.82-83; Lüning (1988)1991.27-93; Todorova 1989.14-15; 1998.27-54; Todorova and Vajsov 1993; Demoule and Perlès 1993.355-416; Parzinger 1993.254-255; Gallis 1994.58; van Andel and Runnels 1995.481-500; Tringham 2000.23-29; Perlès 2001) (Fig. 1).

However, emphasis has been laid recently on the fact that the growing evidence of the pottery deposited in the so-called aceramic layers in Argissa, Sesklo, Soufli Magula, Gentiki and Achilleion in Thessaly, Franchthi and Dendra in the Argolid, and at Knossos in Crete strongly suggest that the Pre-pottery Neolithic in Greece did not exist (Bloedow 1991. 1-43; Gallis 1994.58; 1996.32; Perlès 1990. 130137; 2001.64-97).

Milojčićs successive phasing of Early Neolithic in Thessaly and the sequential diffusion of monochrome, painted and impresso pottery concerns, for the time being, has no chronological value although they maintain "a critical place because of its importance for dating" (Gallis 1994.58; 1996.120). It is not only that impresso pottery (Presesklo or Vorsesklo phase) occurred side by side with the red-onwhite painted pottery in the Protosesklo phase (Thissen 2000a.164), as recent research in Thessaly has shown, but the impresso decoration that "...was made with the finger nail (nail impressions) or by pinching clay between the finger and thumb, and by deeper nail impressions (barbotine), known from the early levels of the EN." (Gallis 1996.120). It follows, then, that a "monochrome" phase of undecorated pottery in sensu stricto in Thessaly did not exist 
and in consequence all the cross-cultural correlations based on the supposition of its appearance and distribution in Southeast Europe must be reconsidered.

However, the interpretation of the processes of neolithisation in the Eastern Balkans is still closely connected with the distributions of "monochrome" and/ or white painted pottery. Two alternative approaches have been proposed recently. The first is based on the premise that the sequence of Early Neolithic phases in the central and eastern Balkans (Karanovo I-III) corresponds with the succession of the colours that have been used in colouring the (tulip beaker) pottery: white, wine red, brown and polychrome. While white is the one and only colour that marked the first phase, wine red and brown appeared in the second, and polychrome at the end of the third phase (Nikolov 1990.63). The similarity to the Thessalian sequence proposed by Milojčić and Schachermeyr is, of course, not coincidental, although $\mathrm{Ni}$ kolov hypothesised direct communication between Karanovo and Haçilar and that groups of Neolithic people migrated from the south (mainly from Anatolia) along the Struma and Mesta river valleys, settled in Upper Thrace in the Early Neolithic and gradually colonised northern Bulgaria later (Nikolov 1988.29-30; 1990.63-69; Stefanova 1996.15-19). The initial Early Neolithic phase Elešnica, identified in the Mesta valley was recently correlated with Haçilar IX-VI and Ilipinar X levels (Nikolov 1997.140).

Todorova and Vaysov posited the second (1993; 1998). They believe the initial neolithisation is reflected in the distribution of "monochrome" pottery in the Balkans that is identified as the "Balkan Monochrome Neolithic" and its appearance in Europe has to be embedded in the context of a Balkan-Anatolian cultural koine and closely connected with the "great migration" in mid seventh millennium $B C$ that began from south Central Anatolia, entering Europe via Thessaly and on an estuary of the Marica river. It is interesting to note that the colonisation of the southern and northern Balkans supposed to have happened almost simultaneously in the period between 6400 and $6100 \mathrm{cal} \mathrm{BC}$ (Fig. 2). Todorova objectifyies the Bal- kan Monochrome Neolithic as a package of monochrome (undecorated) and impresso pottery, the stone tool assemblage consists of "microliths and typical trapezes", "poorly developed agriculture" indicated by the occurrence of lentils and einkorn and the domesticated sheep and goats that have been found in Poljanica, Orlovec, Koprivec and Obhodov (Todorova 1989.11-12; 1998.27-36). Several phases of its development were assumed to be similar to the development in Asia Minor. The latest is supposed to correlate with the appearance of white painted pottery in the Karanovo complex (Todorova 1998.35-36; Vajsov 1998.108). According to the ${ }^{14} \mathrm{C}$ series from Poljanica the site is dated to 6180-6120 cal BC at $1 \sigma$ (Nikolova 1998. 128).

It is worth remembering that the correlations with the Impresso (cardium) complex in the Adriatic were hypothesised in two interpretative contexts. While the first, embedded in the concept of "eastwest" distribution in Eurasia, Anatolia and Greece remains out of the main route, the "Syrian impresso technique" is supposed to have spread "from Asia

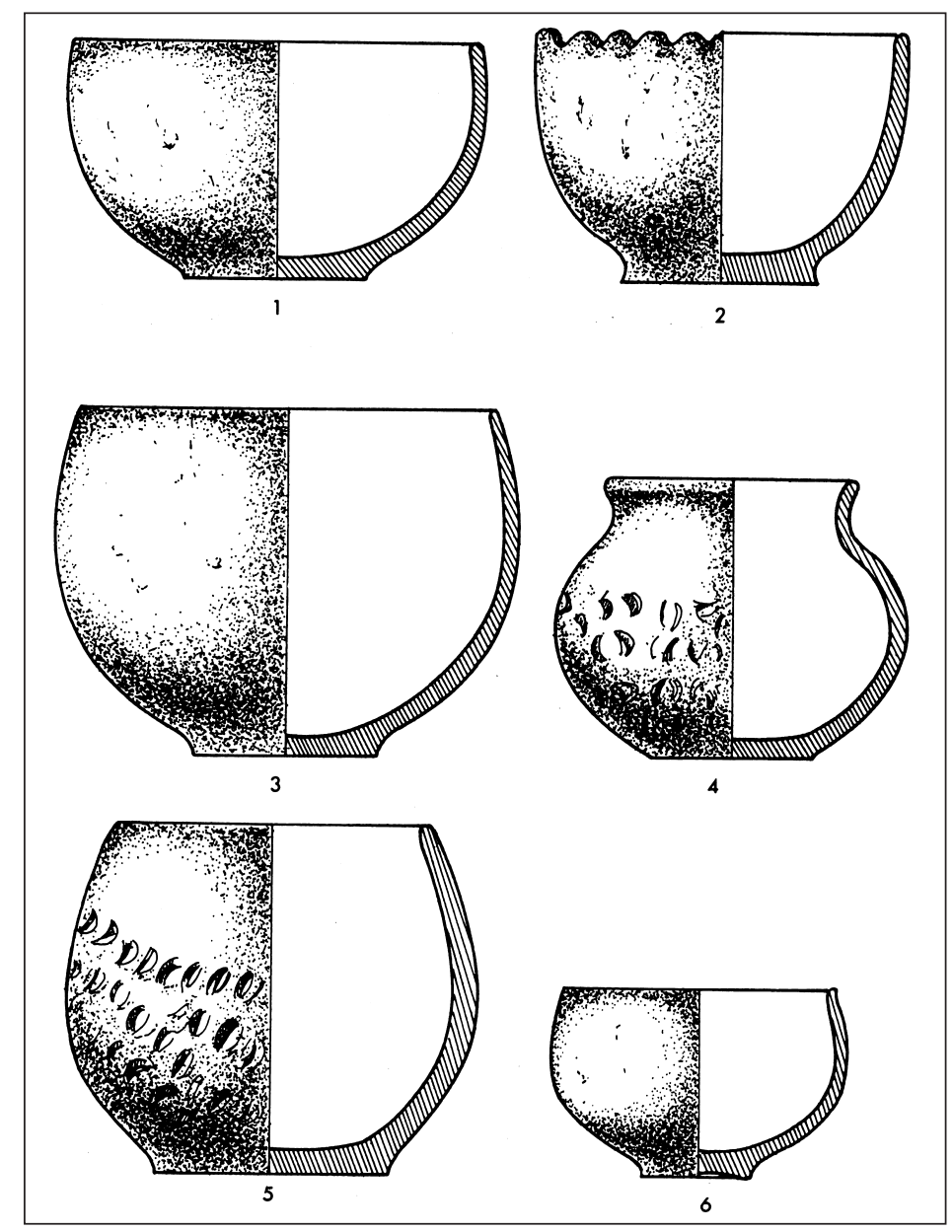

Fig. 6. Monochrome and impresso pottery in Lepenski Vir (after Srejović 1971.Tafel 8). 
Minor to the Dinaric-Adriatic region first" from where it dispersed to the Balkans, the Danube region and at times to northern Greece (Schachermeyr 1976.46). There are two alternative chronological interpretations of cross-cultural connections available. Milojčić himself favoured the idea of asynchronous development in the Balkans region and therefore correlates the beginning of the Neolithic in the Adriatic with its end in Thessaly. Thus the genesis of the Adriatic Impresso (cardium) complex was parallel to the late Presesklo and Sesklo periods (Milojčic 1973 b. 6; Müller 1991.339; 1994.220221). Batović, however, hypothesised that the appearance of pottery in Dalmatia (impressocardium) and Thessaly (monochrome) was coeval, although it appeared in different regional cultural contexts (Batović 1966. 122, 234-235).

However, Batovićs basic idea has been recently actualised in the second interpretative context favouring the concept of "monochrome" pottery distribution first. Its relative synchronous appearance, objectified in "horizon Ib" (Parzinger 1993.253254), was postulated on the cross-regional axis from Çatal Höyük in Central Anatolia across Thessaly (!) to Škarin Samograd in the Eastern Adriatic (Müller 1988.233; 1991.338; Parzinger 1993.53, 254; Chapman 1994.133-156). Having analysed the stratigraphic sequences and corresponding pottery assemblages in the region, they found monochrome pottery in a cave site at Škarin Samograd deposited in the lowest layer superimposed with a later one that contains impresso-cardium pottery. Müller and Parzinger applied the typological sequence to the whole region, maintaining the concept of initial Neolithic that has to be correlated with the appearance of monochrome pottery. Not for long; a year later, Müller, when contemplating the Adriatic neolithisation process and the genesis of Impresso culture pointed out that in the micro region two incompatible sequences are available and that, in fact, impresso-cardium pot-
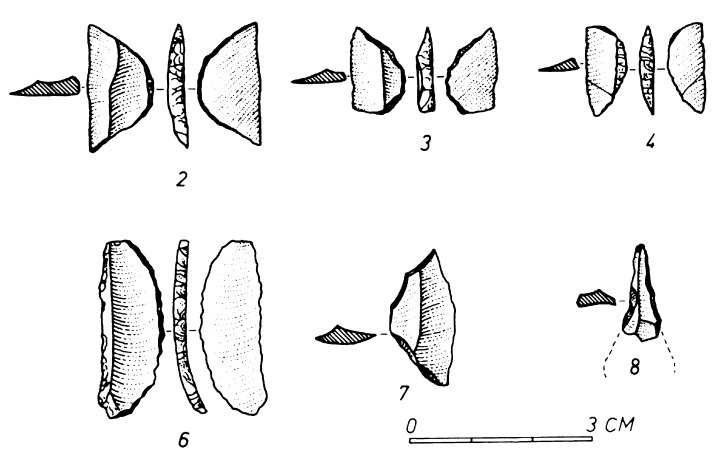

10
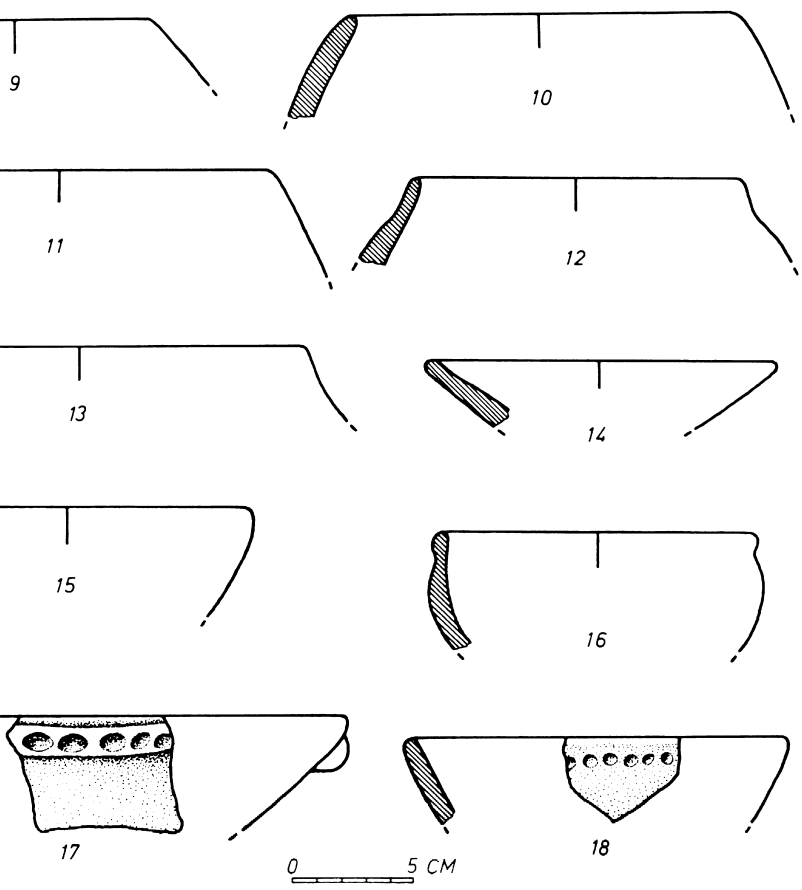

CM

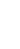
grad the monochrome pottery was indeed deposited in an older layer (5730-5530(5630) cal BC at $1 \sigma$ ) than the impresso-cardium (5620-5490(5540) cal $\mathrm{BC}$ at $1 \sigma$ ) but on the flat, stratified site at Pokrovnik, located in close proximity, the later was recorded in all the lowest, Early Neolithic phases I-III and, according to available ${ }^{14} \mathrm{C}$ dates $(5970-5760$ (5840) cal BC at $1 \sigma$ ) it is older (Müller 1994.112$123,125,182-185,347)$.

Finally, Müller in modelling the Early Neolithic typological sequence in the Adriatic, contrary to Parzinger (1993), objectified the sequential phases in such a way that impressed ornaments (shaped by fingertip, fingernail and awls) determine the initial phases of Impresso A. Shell (Carduium sp.) impressions appeared later, determining phases Impresso A2, B1-2 and C (Müller 1991.322-328; 1994.149-156) (Figs. 3 and 4). Thus the neolithisation of the Eastern Ad- 
riatic was consequently linked to:

- the secondary centre of neolithisation hypothesised for eastern Sicily and Southern Italy,

- the spread of the impressed pottery, domesticates and cultivates across the Adriatic Sea, and along the eastern coast towards the northern Adriatic,

- the gradual colonisation of the Eastern Adriatic coast and its hinterland, supposedly based on an evaluation of the difference in the ${ }^{14} \mathrm{C}$ the dates of the earliest Neolithic deposits in the region that matches the two isochronal lines of

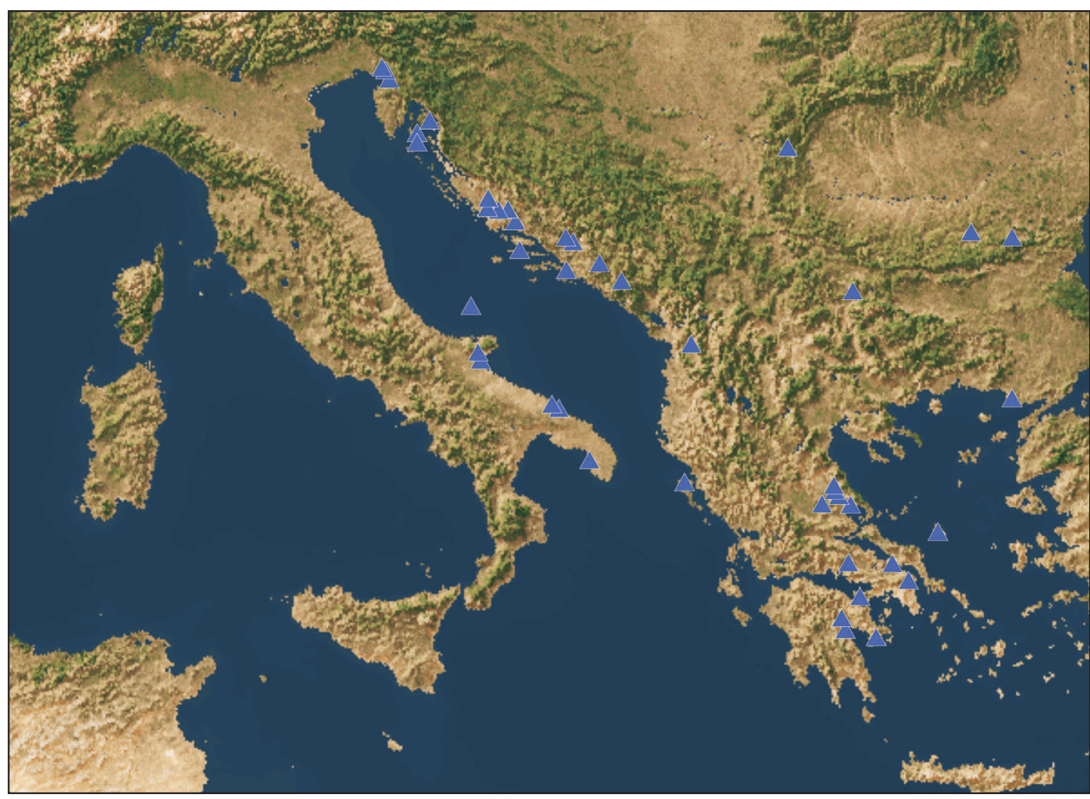

Fig. 8. Monochrome-impresso pottery dispersal (after Müller 1988.Abb. 1; Vajsov 1998.Map 1; Todorova 1998.27-36).
Neolithic expansion at a 500 year interval, as defined in this part of Europe by Ammerman and Cavalli-Sforza,

- postulates that the distribution of impresso-cardium pottery in Adriatic reflects the area of farming colonisation and, its most northern extension represents the boundary to a refuge of hunters which supposedly lay beyond (Müller 1991. 311-358; 1994; Chapman and Müller 1990. 127134; Forenbaher 1999.521-530; for comments see Budja 1993.188-189; 1996.72-73).

\section{POTTERY IN THE CONTEXT OF THE TRANSITION TO FARMING IN SOUTHEAST EUROPE: READING THE PALIMPSEST}

It is time, we believe, to point out some facts concerning pottery appearance, its distribution and its technological as well symbolic meanings in the palimpsest of the transition to farming in Southeast Europe.

The pottery in so-called late Mesolithic contexts, although being broadly accepted, still maintains marginal interpretative value thus on the regional as well on the continental level. The demarcation between the "monochrome" and "impresso" pottery distributions that objectifies two, by definition distinct, "cultural and ethnic" complexes in the Balkans and the Adriatic is apparent. The boundary has been set in the region, indeed, but its later appearance correlates with the Early Neolithic painted pottery distributions.
Furthermore, Thessalian pottery is considered either a local invention (Thissen 2000a.305; 2000b.148149), or a result of the indirect diffusion of constitutive Neolithic items such as painting, mud-brick houses and agriculture from Anatolia (Schubert 1999. 201). However, it is the fact as stated by Thissen, that according to "... our calibrations the first pottery Neolithic sites in Thessaly date to approximately 6200 cal BC". These sites were settled two centuries earlier than the first occupation at Ilipinar and Fikirtepe in western Anatolia and the Marmara region and of Hoca Çeşme in the Marica River delta in southeast Thrace. Moreover, interpreting the results of the analysis of pottery assemblages from western Anatolia and the southern Balkans, he pointed out that the similarities in pottery are too general to "attest for an Anatolian origin of the Thessalian ceramics" and that Thessalian pottery production was developed on the spot and "not as part of the baggage of the immigrants" (Thissen 2000a.133, 194195; 20006.148-149). An "early monochrome" horizon embedded in the context of "the earliest known settlement of agriculturalist and pastoralist" was recently identified at Asphaka in Epirus, and dated to $7380 \pm 240$ BP (Douzougli 1996.46, 117).

The situation in the Peloponnese is different as it was contemplated recently. There "we have at least two different pottery traditions: a Thessalian one and a Southern Greek one, neither related in time nor in origin." These different traditions reflect supposedly different patterns of neolithisation of both regions (Thissen 2000a.193; 2000b.144-140). 
We have already pointed out that the most northerly and the most westerly distribution points of monochrome-impresso pottery in southeast Europe have been fixed in hunter-gatherer contexts (Budja 1996.73-74; 1999.134-136). The first is embedded in the Lepenski Vir culture in the Danube Gorges region. Unfortunately, most of the pottery assemblages are still scantily published and being discussed from the very beginning as matters of taphonomic filter and stratigraphic problems of vertical displacement and post-depositional disturbance. The presence of in situ pottery was recently directly confirmed inside Lepenski Vir: 4, 28, 36, 54 and Padina: 2, 3, 5, 6, 7, 12, 17 trapezoidal houses (Borić 1999. 49-53; Garašanin \& Radovanović 2001.118-125) (Figs. 5 and 6). They have been recognized as Lepenski Vir Ib-e or I/2-3 (e. g. IGM IV-V) Mesolithic phases (Srejović 1969.39; 1973.252-253; Radovanovic 1996.287-290).

Monochrome-impresso pottery appeared in the package together with geometric microliths and a new Montbani blades technique and, it was stratigraphicaly separated from the white painted pottery that was recognised as the marker of the Neolithic Starčevo and Gura Baciului cultures (i.e. the Balkan-Anatolian complex of the Early Neolithic) ( $R a$ dovanovic 1996.287; Garašanin $\mathcal{E}$ Radovanović 2001.121).

It was confirmed recently that the pottery appeared in the context of "an intermediate phase" from a Mesolithic-type dietary regime, based largely on aquatic resources and then to one based largely on terrestrial resources that "probably included a major agricultural component" (Bonsall et al. 2000.119-132). While the transitional phase was dated in the

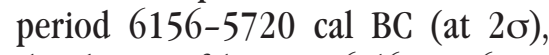
the dating of house 36 (6390-6020 cal $B C$ at $2 \sigma)$ and $54(6170-6130 \mathrm{cal}$ $B C$ at $2 \sigma$ ) in Lepenski Vir seem to predate the process. However, Bonsall et al. (2000.129) have pointed out, the charcoal samples were from long-lived tree species (oak and elm) and, such samples can yield ${ }^{14} \mathrm{C}$ ages that are several hundred years older than the archaeological events they purport to date (the "old wood" effect).
Lepenski Vir pottery appearance chronologically corresponds well with pottery in Achilleion (6240$6160 \mathrm{cal} \mathrm{BC}$ at $2 \sigma)$, Nea Nikomedeia $(6140-6080 \mathrm{cal}$

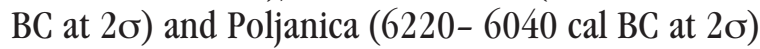
as discussed above (Bonsall et al. 2000.128; Thessien 2000b.147-148, Fig. 6, 8; Nikolova 1998.128).

The most westerly distribution point of monochrome-impresso pottery is fixed for now in Edera (Stenašca) Cave in Trieste Karst. The context where the pottery was deposited is described as a well-defined fireplace in layer $3 \mathrm{a}$. The monochrome (unornamented) pottery was associated with a flint assemblage, "composed of 538 artefacts (shatter included), 61 microburins, 1 core fragment, 1 denticulated bladelet, 1 short endscraper, 2 truncations and 2 trapezes" (Biagi, Starnini, Voytek 1993.48). Faunal remains, besides a great amount of marine shellfish remains, were ascribed to 14 individual mammals; half of them belong to a group of domestics: caprines $(40.7 \%)$, cattle $(4.4 \%)$ and domestic pig-wild boar (5.9\%) (Boschin and Riedel 2000.74, 83). The assemblage is determined as a Mesolithic, Late $\mathrm{Ca}$ stelnovian hunter-gatherer complex and dated to

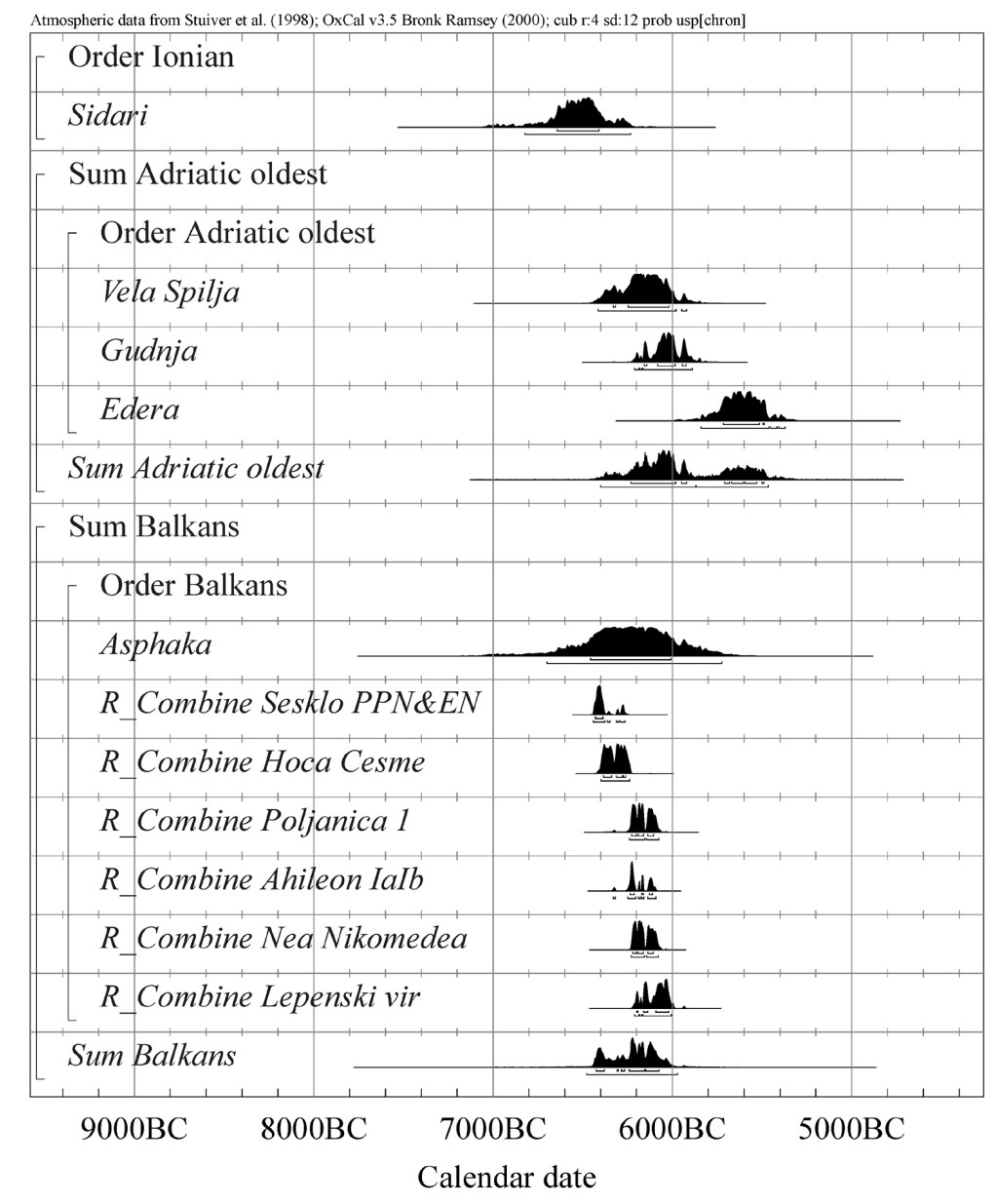

Fig. 9. OxCal radiocarbon sequence of "incipient Neolithic" on Balkans, Ionian and Eastern Adriatic. 
$6700 \pm 130 \mathrm{BP}$ (charcoal sample) (Biagi and Spataro 2001.35).

There are two more sites we can take into consideration: Sidari on Corfu, and Vlushe in Albania. In the later (Vidhëz and Armeninë locations) the monochrome pottery has been connected to Mesolithic traditions in the production of geometric microliths (Prendi 1990.401. Korkuti 1995.29-32) (Fig. 7). At Sidari on Corfu, on the Ionian coast, a first Neolithic phase (level C -base) with evidence of impresso pottery, atypical microliths, as well as sheep and goat and an Early Neolithic stratum (level C - top) contain impresso-cardium pottery were separated by a sterile layer. The lower context is dated to $7670 \pm$ $120 \mathrm{BP}$ and the upper to $7340 \pm 180 \mathrm{BP}$ (Sordinas 1967.64; 1969.407; Breunig 1987.91; Perlès 2001. 49).

We mentioned above Müller's evolutionistic interpretation of Early Neolithic sequence on the eastern Adriatic coast based on the corresponding analyses of pottery assemblages and available stratigraphic (vertical and horizontal) sequences of cave and flat sites in the regions. He objectified the sequence in a way that impressed, nipped and stamped ornaments, shaped by fingertip, fingernail and awls, determine the initial phases Impresso A1. Shell-cardium impressed ornaments constitute the successive phases A2, B1-2 and C (Fig. 3 and 4). Interestingly, in Hercegovina, one of the Dinaric regions, the initial ornamental principle evidently maintains a longue durée, as cardium impressed ornaments have never appeared although regularly dispersed some $30 \mathrm{~km}$ distance into the Adriatic hinterland. The A1-2 phases are chronologically embedded in the period $6050-$ 5850 cal BC at $1 \sigma$ (Müller 1991.311-358; 1994.145162, 182-185).

The earliest impresso pottery assemblages appeared in cave sites at Gudnja on Pelješac peninsula and Vela špilja on Korčula island. Having discussed the relevance of the dates in the context of the gradual colonisation of the Eastern Adriatic coast, we mentioned the unreliable stratigraphic correlations between the charcoal samples and artefact depositions (Budja 1996.7273). However, the excavator of the Vela špilja deposit confirms recently the hypothesised correlation of $14 \mathrm{C}$ dates $(7300 \pm 120 \mathrm{BP})$ and pottery assemblage, ornamented "exclusively by fingertip and awls impressions" (Čécuk, Radić 2001.88, 102, 108). The available dates of Impresso A1 pottery assemblage in Gudnja cave are $7170 \pm 70 \mathrm{BP}$ and $6935 \pm$ 50 BP (Müller 1994.348).

\section{IN PLACE OF CONCLUDING REMARKS}

It is shown in Figures 8 and 9 that monochrome-impresso pottery appeared in a wide area, but in a narrow time span in the Balkans, Ionian and Adriatic. In many cases it was closely connected with huntergatherers' stone tool sets. There is no direct evidence of pottery production available, but we have to take into account the presence of some unbaked clay masses, as well as some associated monochrome, primitive and slightly baked pottery that has been documented in late Mesolithic context in Theopetra Cave (Kyparissi-Apostolika 2000.136). We pointed out the well-grounded hypothesis "...that "Thessalian ceramic procedures were developed on the spot and not as part of the baggage of immigrants." (Thissen 2000b.148; but see also Thissen 1999.29-40 and 2000a). The pattern of monochrome-impresso pottery distribution, indeed, contradicts the concepts of secondary centres of neolithisation and of the fertile core area in Thessaly, where an integrated Neolithic

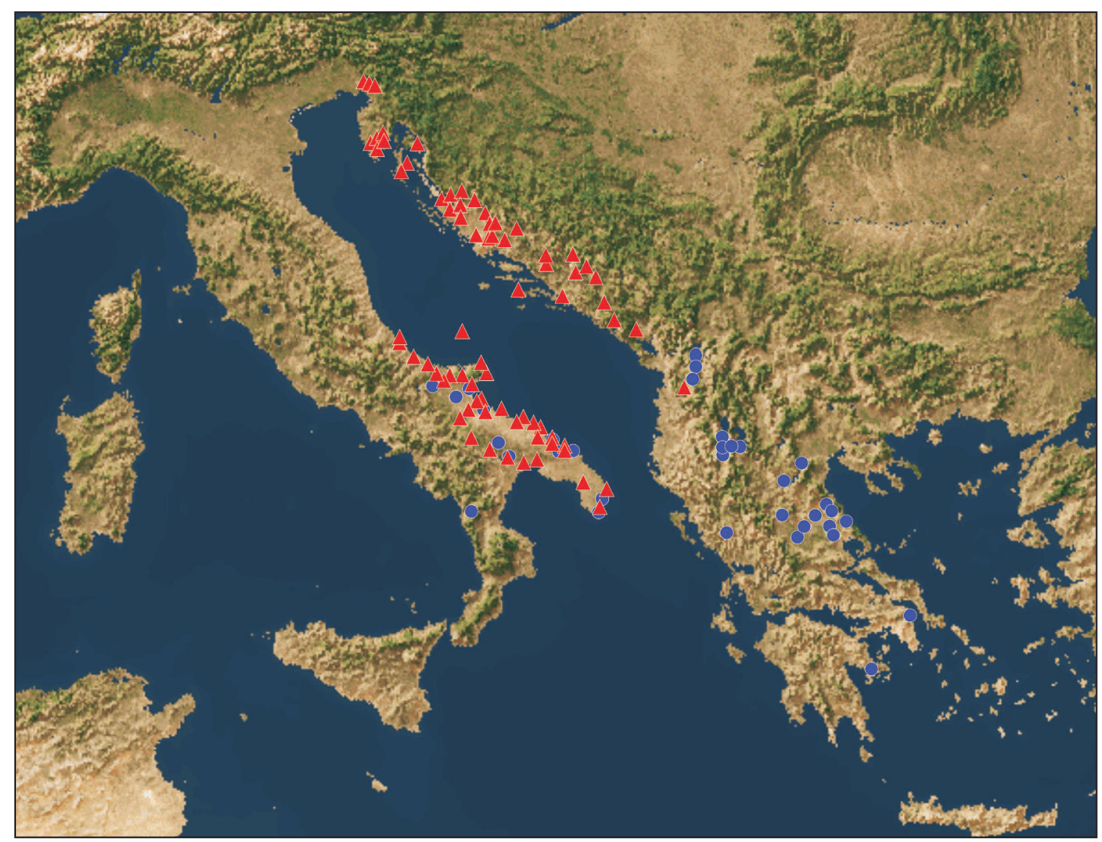

Fig. 10. Impresso-cardium and "red painted" pottery distributions (after Müller 1994.Abb. 81. and 92; Marjanović 2000.77, S1. 7). 
package is supposed to have arrived first and exclusively (van Andel et al. 1995.131144; van Andel and Runnels 1995.481-500). We mentioned as well that the Balkans Neolithic wheat harvesting pattern differs from that of the Levant. While emmer and barley wheat prevailed there, einkorn was more frequent in the Balkans. Therefore the presence of wild einkorn wheat (Triticum boeoticum) in a Mesolithic context in Theopetra Cave does not seem random because it is near its present-day habitats in Grevena region.

It was hypothesised that monochrome-impresso pottery in

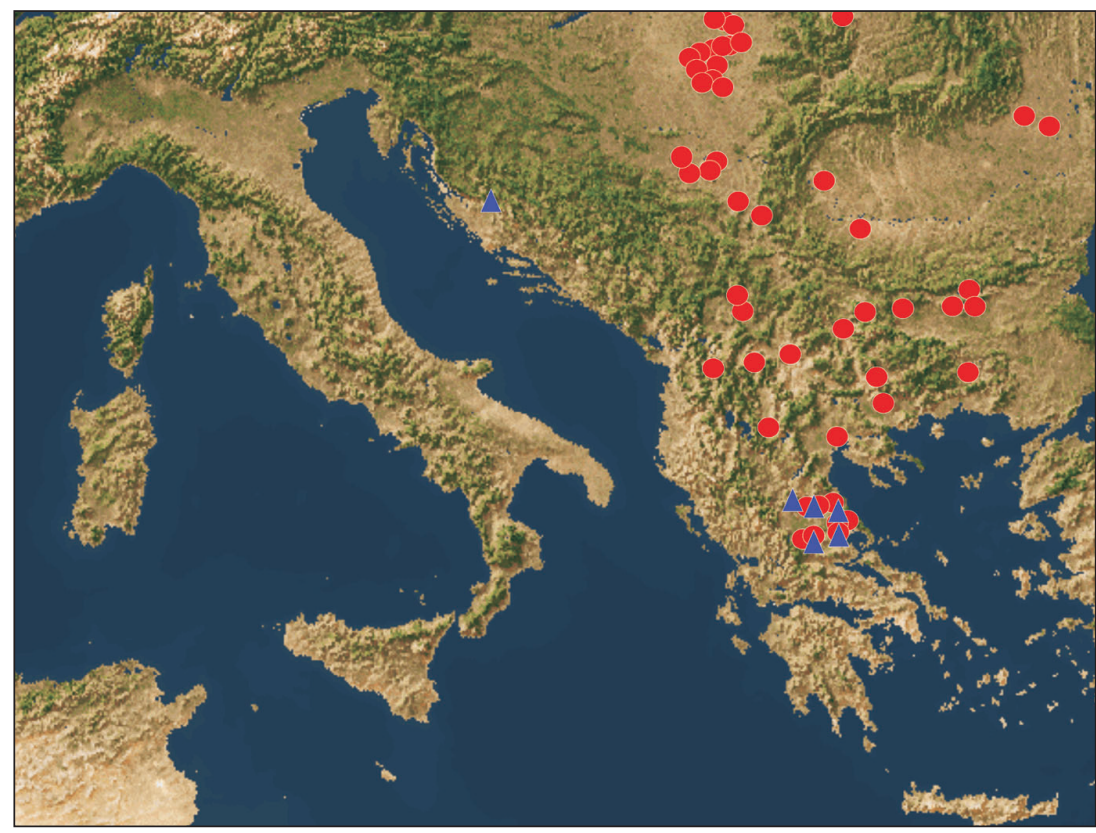

Fig. 11. The distributions of Early Neolithic "stamp seals" (O) and tokens (A) (after Budja 1998.219-235). hunter-gatherer contexts at the ends of its dispersal objectify a centralised, either gradual cultural diffusion towards the marginal ends of the Early Neolithic koine or sequential demic diffusion and colonisation. I believe, on the contrary, that it marks a dispersed and selective course toward a farming adaptation in the Balkans, Ionian and Adriatic. While being aware of taphonomic filters operating in the contexts of unsystematic research procedures, inconsistent interpretative postulates and weak ${ }^{14} \mathrm{C}$ databases, it seems indeed the process in the Adriatic differs from that in Ionia and the Balkans. In the Corfu, Epirus, Thessaly, Thrace and Danube regions the process of transition to farming was, according to available data, simultaneous and correlative. In the Adriatic the process seems to be unequal (Fig. 9). The distinction between the two areas became obvious when impresso cardium and painted pottery were adopted. The spatial dispersals of two ornamental techniques do not overlap (Fig. 10). Therefore, we may hypothesise the internal "border" formed not between hunter-gatherers and farmers, but incipient farmers in the eastern Adriatic and those in Ionia and Balkans. It seemed to be immediately after the period of incipient regional farming adaptations.

Parallel with painted pottery, a discrete set of items: anthropomorphic figurines, stamp seals, tokens and stylised amulets (the so-called labrets/lobates and earplugs) have been attested in the Balkans Early Neolithic. It was embedded in a trans-Aegean net- work, initially based on Melian obsidian transmits, exchange networks and long-distance connections and, Near Eastern origins, most of which have been broadly accepted (Nandris 1970.192-213; Makkay 1974.131-154; 1984; Renfrew 1987.341-374; Müller 1991.337-338; 1994.218-219; 2000.151-159; Perlès 1992.115-164; 2001.54-58, 78-79, 287288, 296-297; Onassoglou 1996.163-164; Vajsov 1998.108; Budja 1998.219-235). Some of them have been interpreted recently as tokens - counters used for calculating quantities of goods in systems of exchange (Budja 1998.219-235) and messengers between villages, particularly in times of crisis, or even as markers of inter-village marital connections (Talalay 1993.45-46).

However, almost none of the items have crossed the border on the eastern Adriatic coast. There was a single exception, a token found in the context of the Impresso-cardium culture in Vrbica site (Budja 1998. 220-222) (Fig. 11). We can speculate therefore that region after adopting incipient farming did not enter a network of reliable integrative mechanisms maintained through regional exchanges. We may also presuppose society was self-contained and static externally and, as Perlès argues, in such a society there are social barriers to engaging and maintaining the circulation of goods and/or people over long distances (Perlès 1992.121).

It is not our intention to discuss the conceptualisation of "availability" and "substitution" phases of ag- 
ricultural transition as well the principles of forager-farmer interactions and mobility within frontier zones (see Zvelebil in this volume) but, to point out that as such, external frontiers do not, we believe, correlate either with "wave of advance" or gradual "demic expansion". The internal boundaries that appeared after the initial adoption of domesticates or substitution wild resources with domesticates we believe related to intensity of processes of social and ideological restructuring of forager and the hunter- gatherer communities. They reflect an isolationism that may be seen as a strong dominance of social and ideological continuity. The incoming near eastern lineages and the difference of the values for the Balkans $(\sim 20 \%)$ and Mediterranean coastal area, including the Adriatic $(\sim 10 \%)$ which we discussed above can not be linked to incipient farming, but to a network of the circulation of goods and people over long distances that was consequentially set up later.

\section{REFERENCES}

ALLABY R. 2000. Wheat Domestication. In C. Renfrew and K. Boyle (eds.), Archaeogenetics: DNA and the Population Prehistory of Europe: 321-324.

AMMERMAN A. J. and CAVALLI-SFORZA L. L. 1984. The Neolithic Transition and the Genetics of Populations in Europe. Princeton University Press. Princeton.

BATOVIĆ Š. 1966. Stariji neolit u Dalmaciji. Dissertationes II. Zadar.

BENAC A., GARAŠANIN M., SREJOVIĆ D. 1979. Uvod. Praistorija jugoslovanskih zemalja II. Neolitsko doba: 11-31. Sarajevo.

BERNABEU AUBÁN J. 1997. Indigenism and Migrationism.The Neolithisation of the Iberian Peninsula. Porocilo o raziskovanju paleolitika neolitika in eneolitika v Sloveniji XXIV: 1-18.

BIAGI P., STARNINI E., VOYTEK B. 1993. The late Mesolithic and Early Neolithic Settlement of Northern Italy: Recent Consideration. Porocilo o raziskovanju paleolita, neolita in eneolita v Sloveniji XXI: 45-58.

BIAGI P. and SPATARO M. 2001. Plotting the evidence: some aspects of the radiocarbon chronology of the Mesolithic-Neolithic transition in the Mediterranean basin. Atti della Società per la Preistoria della Regione Friuli Venezia-Giulia XII: 15-54.

BLOEDOW F. E. 1991. The "Aceramic" Neolithic Phase in Greece Reconsidered. Mediterranean Archaeology 4: 1-43.
BONSALL C. et al. 2000. Stable Isotopes, Radiocarbon and the Mesolithic-Neolithic Transition in the Iron Gates. In M. Budja (ed.), Documenta Praehistorica XXVII: 119-132.

BORIĆ D. 1999. Places that created time in the Danube Gorges and beyond, $c$. 9000-5500 BC. In M. Budja (ed.), Documenta Praehistorica XXVI: 4170.

BOSCHIN F. and RIEDEL A. 2000. The Late Mesolithic and Neolithic of the Edera Cave (Aurisiana, Trieste Karst): a preliminary report. Atti della Società per la Preistoria della Regione Friuli Venezia-Giulia. Quaderno 8: 73-90.

BREUNIG B. 1987. C14 - chronologie des vorderasiatischen, sudost-und mitteleuropaischen Neolithikums. Fundamenta. Monographien zur Urgescichte A13.

BROWN A. T. 1999. How ancient DNA may help in understanding the origin and spread of agriculture. Philosophical Transactions of the Royal Society of London. Sries B. Volume 354. Number 1379: 8998.

BUDJA M. 1993. The Neolithisation of Europe. Slovenian aspect. Poročilo o raziskovanju paleolita, neolita in eneolita v Sloveniji XXI: 163-193.

1996. Neolithisation in the Caput Adriae region: between Herodotus and Cavalli-Sforza. Poroćilo o raziskovanju paleolitika neolitika in eneolitika v Sloveniji XXIII: 61-76. 
1998. Clay tokens - accounting before writing in Eurasia. In M. Budja (ed.), Documenta Praehistorica 25: $127-136$.

1999. The transition to farming in Mediterranean Europe - an indigenous respond. In M. Budja (ed.), Documenta Praehistorica XXVI: 119-142.

CAVALLI-SFORZA L. L. and CAVALLI-SFORZA F. 1995. The Great Human Diasporas. The History of Diversity and Evolution. Addisson - Wesley Publishing Company. Reading.

CAVALLI-SFORZA L. L. 1996. The spread of agriculture and nomadic pastoralism: insights from genetics, linguistics and archaeology. In D. R. Harrris (ed.), The Spread of Agriculture and Pastoralism in Eurasia: 51-69.

CAVALLI-SFORZA L. L., MENOZZI P., PIAZZA A. 1993. Demic Expansion and Human Evolution. Science 259: 639-646.

CAVALLI-SFORZA L. L. and MINCH E. 1997. Palaeolithic and Neolithic Lineages in the European Mitochondrial Gene Pool. American Journal of Human Genetics 61:247-251.

CHAPMAN J. C. 1989. Demographic Trends in Neothermal South-East Europe. In C. Bonsall (ed.), The Mesolithic in Europe. Papers Presented at the Third International Symposium: 500-515.

1994. The Origins of Farming in South East Europe. Préhistoire Europé 6: 133-155.

CHAPMAN J. \& MÜLLER J. 1990. Early farmers in Dalmatia. Antiquity 64/242: 127-134.

CLARK J. G. D. 1965. Radiocarbon dating and the expansion of farming from the Near East over Europe. Proceedings of the Prehistoric Society 21: $58-73$

CAUVIN J. 2000. The Birth of the Gods and the Origins of Agriculture. Cambridge University Press. Cambridge.

ČEČUK B., RADIĆ D. 2001. Vela špilja - preliminarni rezultati dosadašnjih istraživanja. Arheološka istraživanja na području otoka Korčule i Lastova. $\mathrm{Hr}$ vatsko arheološko društvo. Znastveni skup. Vela Luka i Korčula, 18-20. travnja 1991: 75-118.
DEMOULE J. P. and PERLÈS C.1993. The Greek Neolithic: A New Review. Journal of World Prehistory 7/4: 355-416.

DOUZOUGLI A. 1996a. Epirus - The Ionian Islands. In G. A. Papathanassopoulos (ed.), Neolithic Culture in Greece: 46-48, 117-119.

ERNY-RODMAN C., GROSS-KLEE E., HASS J. N., JACOMET S. \& ZOLLER H. 1997. Früher "human impact" und Ackerbau im Übergangsbereich Spätmesolithikum-Frühneolithikum im Schweizerischen Mittelland. Jahrbuch der Schweizerischen Gesellschaft für Ur-und Frühgewchichte 80: 27-56.

FORENBAHER S. 1999. The earliest Islanders of the Eastern Adriatic. Collegium Anthropologicum 23: 521-530.

GALLIS J. K. 1994. Results of recent Excavations and topographical work in Neolithic Thessaly. La Thessalie. Volume A: 57-60.

1996. The Neolithic World. In G. A. Papathanassopoulos (ed.), Neolithic culture in Greece: 23-37.

GARAŠANIN M. 1979. Centralnobalkanska zona. Praistorija jugoslovenskih zemalja II. Neolitsko doba: 79-212. Sarajevo.

GARAŠANIN M. \& RADOVANOVIĆ I. 2001. A pot in house 54 at Lepenski Vir I. Antiquity 75/287: 118125.

HALSTEAD P. 1996. The development of agriculture and pastoralism in Greece: when, how, who and what. In D. R. Harrris (ed.), The Spread of Agriculture and Pastoralism in Eurasia: 296-309.

HARRIS D. R. 1989. An evolutionary continuum of people-plant interaction. In D. R. Harris, G. C. Hillman (eds.), Foraging and Farming. One World Archaeology 13: 11-26.

1996a. Introduction: themes and concepts in the study of early agriculture. In D. R. Harrris (ed.), The Spread of Agriculture and Pastoralism in Eurasia: 1-9.

1996b. The origins and spread of agriculture and pastoralism in Eurasia: an overview. In D. R. Harris (ed.), The Spread of Agriculture and Pastoralism in Eurasia: 552-574. 
HAWKES K. and O'CONNEL J. 1992. On Optimal Foraging Models and Subsistence Transitions. Current Anthropology 33/1. 63-65.

HEUN M., SCHAFER-PREGL R., KLAWAN D., CASTAGNA R., ACCERBI M., BORGHI B. and SALAMINI 1997. Site of Einkorn Wheat Domestication Identified by DNA Fingerpinting. Science 278: 1312-1314.

HEUN M., BORGHI B. and SALAMINI F. 1998. Einkorn wheat domestication site mapped by DNA fingerprinting. In M. Budja (ed.), Documenta Praehistorica XXV: 65-69.

JACKES M., LUBELL D. and MEIKLEJOHN C. 1997. Healthy but Mortal: Human Biology and the First Farmers of Western Europe. Antiquity 71/273: 639658.

KORKUTI M. 1995. Neolithikum und Chalkolithikum in Albanien. V Heidelberger Akademie der Wissenschaften. Monographien B. IV. Mainz am Rhein.

KYPARISSI-APOSTOLIKA N. 2000. The Mesolithic/ Neolithic Transition in Greece as Evidenced by The Data at Theopetra Cave in Thessaly. In M. Budja (ed.), Documenta Praehistorica 2000:133-140.

LAMBECK K. 1996. Sea-Level Change and Shore-Line Evolution in Aegean Greece Since Upper Palaeolithic Time. Antiquity 70/269: 588-611.

LAYTON R., FOLEY R. and WILLIAMS E. 1991. The Transition between Hunting and Gathering and the Specialized Husbandry of Resources. Current Anthropology 32/3: 255-274.

LÜNING J. (1988)1991. Frühe Bauern in Mitteleuropa im 6. und 5. Jahrtausend v. Chr. Jahrbuch des Römisch-Germanischen Zentralmuseums 35/1: 27-93.

MAKKAY J. 1974. "Das frühe Neolithikum auf der Otzaki Magula" und die Körös-Starčevo Kultur. Acta Archaeologica Academiae Scientiarum Hungaricae XXVI:131-154.

1984. Early Stamp Seals in South-East Europe. Budapest.

MARJANOVIĆ B. 2000. Prilozi za prapovjest u zaleđu Jadranske obale. Monografije. Svezak 2. Filozofski fakultet. Zadar.
MEIKLEJOHN C., WYMAN J. J., JACOBS K. and JACKES M. K. 1997. Issues in the Archaeological Demography of the Agricultural Transition in Western and Northern Europe: A View from the Mesolithic. In R. R. Paine (ed.), Integrating Archaeological Demography: Multidisciplinary Approaches to Prehistoric Population: 311-326. Center for Archaeological Investigations, Occasional Paper No. 24. Southern Illinois University, Carbondale.

MENOZZI P., PIAZZA A., CAVALLI-SFORZA L. L. 1978. Synthetic maps of human gene frequencies in Europeans. Science 201: 786-792.

MILOJČIĆ V. 1952. Die frühesten Ackerbauer in Mitteleuropa. Germania 30. 3/4: 313-318.

1956. Die erste praekeramische baeuerliche Siedlung der Jungstenzeit in Europa. Germania 34. 3/4: 208-210.

1959. Ergebnise der Deustschen Ausgrabungen in Thessalien (1953-1958). Jahrbuch des RömischGermanische Zentralmuseums Mainz 6: 1-56.

1960. Praekeramisches Neolithikum auf der Balkanhalbinsel. Germania 38, 3/4: 320-335.

1973a. Zur Frage eines präkeramischen neolithikums in Mitteleuropa. Actes du VIIJ congres international des sciences prehistoriques et protohisatoriques. Tome 2: 248-251.

1973b. Die C14 Methode im Lichte der Komparativ-stratigraphischen Befunde. Actes du VIIIe congres international des sciences prehistoriques et protohisatoriques. Tome 2: 6-11.

MÜLLER J. 1988. Škarin Samograd - eine frühneolithische Station mit monochromer Ware und Impresso-Keramik an der Ostadria. Archäologisches Korrespondenzblatt 18: 219-235.

1991. Die ostadriatische Impresso-Kultur: Zeitliche Gliederung und kulturelle Einbindung. Germania 69/2: 311-358.

1994. Das ostadriatische Frühneolithikum. Die Impresso-Kultur und die Neolithisierung des Adriaraumes. Prähistorische Archäologie in Südosteuropa 9: 63-69.

2000. "Earplugs", ceramics and sheep: examples of communicatiopn and boundaries in the Ad- 
riatic Early Neolithic. Atti della Società per la Preistoria della Regione Friuli Venezia-Giulia. Quaderno 8: 151-159.

NANDRIS J. 1970. The development and relationships of the earlier Greek Neolithic. Man N.S. 5: 192-213.

NIKOLOV V. 1987. Beitrage zu den Beziehungen zwischen Vorder Asien und Südosteuropa aufgrund der frühneolitischen bemal ten Keramik aus dem Zentralbalkan. Acta Prahistorica et Archaeologica 19: 8-19.

1990. Das Flusstal der Struma an der frühneolithischechen Strasse von Anatolien nach Mitteleuropa. In Die ersten Bauern, Band 2. Zürich.

1997. Periodiserung un Chronologie der südwestlichen Variante der Kultur Karanovo I. In Uzdarje Dragoslavu Srejoviću. Beograd: 139-145.

1998. The Circumpontic cultural zone during the $6^{\text {th }}$ millenium BC. In M. Budja (ed.), Documenta Praehistorica XXV: 81-90.

NIKOLOVA L. 1998. Neolithic sequence: the upper Stryama valley in western Thrace, (with appendix: radiocarbon dating of the Balkan Neolithic). In M. Budja (ed.), Documenta Praehistorica XXV: 99-132.

ONASSOGLOU A. 1996. Seals. In G. A. Papthanassopoulos (ed.), Neolithic culture in Greece: 163-164.

OKAY A. I., DEMIRBAG E., KURT H., OKAY N. and KUSCU I. 1999. An active, deep marine strike-slip basin along the North Anatolian fault in Turkey. Tectonics 18/1: 116-134.

PARZINGER H. 1993. Studien zur Chronologie und Kuturgeschichte der Jungstein, Kupfer-und Frühbronzezeit zvischen Karpaten und Mittlerem Taurus. Römisch-Germanische Forschungen 52. Frankfurt a. M.

PERLÈS C. 1990. Les industries lithiques taillées de Franchthi (Argolide, Grèce). Vol. II. Les industries du Mésolithique et Du Néolithique. In T. W. Jacobsen (ed.) Excavations at Franchthi Cave, Greece, fasc. 5 .

1992. System of Exchange and Organisation of Production in Neolithic Greece. Journal of Mediterranean Archaeology 5/2: 115-164.
2001. The early Neolithic in Greece. The first farming communities in Europe. Cambridge World Archaeology. Cambridge University Press. Cambridge.

PINHASI R., FOLEY R. A., LAHR M. M. 2000. Spatial and Temporal Patterns in the Mesolithic Neolithic Archaeological Record of Europe. In C. Renfrew and K. Boyle (eds.), Archaeogenetics: DNA and the Population prehistory of Europe: 45-56.

PRENDI F. 1990. Le Neolithique ancien en Albanie. Germania 68/2: 400-425.

PRICE T. D., JOHNSON C. M., EZZO E. A., ERICSON E. \& BURTON J. H. 1994. Residential mobility in the Prehistoric Southwest United States: A preliminary study using strontium isotope analysis. Journal of Archaeological Science 21. 315-330.

PRICE T. D., BENTLEY A. R., LÜNING J., GRONENBORN D. \& WAHL J. 2001. Prehistoric human migration in the Linearbandkeramik of Central Europe. Antiquity 75/289: 593-603.

RADOVANOVIĆ I. 1996. The Iron Gates Mesolithic. Ann Arbor: International Monographs in Prehistory, Archaeological Series 11.

RADOVANOVIĆ I. \& VOYTEK B. 1997. Hunters, fishers or farmers: sedentism, subsistence and social complexity in the Djerdap Mesolithic. Analecta Praehistorica Leidensia 29: 19-32.

RENFREW C. 1987. Old Europe or Ancient East? The Clay Cylinders of Sitagroi. In Proto-Indo-European, the Archaeology of a Linguistic Problem. Studies of Maria Gimbutas: 341-374.

2000. Towards a Population Prehistory of Europe. In C. Renfrew and K. Boyle (eds.), Archaeogenetics: DNA and the Population Prehistory of Europe: 3-12.

RICHARDS M. et al. 1996. Paleolithic and Neolithic Linages in the European Mitochondrial Gene Pool. American Journal of Human Genetics 59: 185-198.

RICHARDS M. et al. 2000. Tracing European Founder Lineages in the Near Eastern mtDNA Pool. American Journal of Human Genetics 67: 1251-1276.

RICHARDS M., MACAULAY V. 2000. Genetic Data and the Colonization of Europe: Genealogies and Foun- 
ders. In C. Renfrew and K. Boyle (eds.), Archaeogenetics: DNA and the Population prehistory of Europe: $139-151$.

ROKSANDIĆ M. 2000. Between Foragers and Farmers in the Iron Gates Gorge: Physical Anthropology Perspective Djerdap Population in Transition from Mesolithic to Neolithic. In M. Budja (ed.), Documenta Praehistorca XXVII: 1-100.

RYAN W. B. F. et al. 1997. An abrupt drowning of the Black Sea shelf. Marine Geology 138: 119-126.

SCHACHERMEYER F. 1976. Die Ägäische Frühzeit I. Die Vormykenischen Periode. Des griechichen festlandes und der Kykladen. Österreichiche Akademia der Wissenschaften. Philosophisch-historische Klasse. Sitzungsberichte 303. Band. Wien.

SOKAL R. R., ODEN L. N., WILSON C. 1991. Genetic evidence for the spread of agriculture in Europe by demic diffusion. Nature 351: 143-145.

SORDINAS A. 1967. Radiocarbon dates from Corfu, Greece. Antiquity 41: 64.

1969. Investigations of the prehistory of Corfu during 1964-1966. Balkan Studies 10/2: 393424.

SREJOVIĆ D. 1969. Lepenski Vir. Nova praistorijska kultura u Podwvalju. Beograd.

1971. Die Lepenski Vir - Kultur und der Beginn der Jungsteinzeit an der mittleren Donau. In $\mathrm{H}$. Schwabedissen (ed.), Die Anfänge des Neolithikums vom Orient bis NordEuropa. Teil II. Östliches Mitteleuropa. Fundamenta. Reihe A. Band 3: 1-39.

1973. Die Anfange des Neolithikums im Bereiche des mittleren Donauraumes. Actes du VIIIe congres international des sciences prehistoriques et protohisatoriques. Tome 2: 252-263.

STEFANOVA T. 1996. A comparative Analysis of Pottery from the "Monochrome Early Neolithic Horizon" and "Karanovo I Horizon" and the Problems of the Neolithization of Bulgaria. Poročilo o raziskovanju paleolitika, neolitika in eneolitika v Sloveniji XXIII: 15-19.

SYKES B. 2000. Human Diversity in Europe and Beyond: From Blood Groups to Genes. In C. Renfrew and K. Boyle (eds.), Archaeogenetics: DNA and the Population prehistory of Europe: 13-22.

SYKES B. \& RENFREW C. 2000. Concepts in Molecular Genetics. In C. Renfrew and K. Boyle (eds.), $A r$ chaeogenetics: DNA and the Population prehistory of Europe: 13-22.

TALALAY E. T. 1993. Deities, Dolls, and Devices. In T. W. Jacobsen (ed.), Excavation at Franchthi Cave, Greece. Fasc. 9.

THEOCHARIS R. D. 1973. Neolithic Greece. National Bank of Greece. Athens.

1967. I Avgi tis Thessalikis Proïstorias. Volos.

THISSEN L. 1999. Trajectories Towards the Neolithisation of NW Turkey. In M. Budja (ed.), Documenta Praehistorica XXVI: 29-39.

2000a. Early Village Communities in Anatolia and the Balkans: Studies in Chronology and Culture Contact. Unpublished Ph.D. dissertation. Leiden.

2000b. Thessaly, Franchthi and Western Turkey: Clues to the Neolithisation of Greece? In M. Budja (ed.), Documenta Praehistorica XXVII: 141154.

TODOROVA H. 1989. Das Frühneolithikum Nordbulgariens im kontakte des ostbalkanischen Neolithikums. Tell Karanovo und das Balkan-Neolithikum: 9-26.

1998. der balkano-anatolische Kulturbereich vom Neolithikum bis zr Frühbronzezeit. In M. Stefanovich, H. Todorova, H. Hauptmann (ds.), In The Steps of James Harvey Gaul. Vol. 1: 27-54.

TODOROVA H., VAJSOV I. 1993. Novikamennata epoha v Balgaria (kraja na sedmo-shesto hiljadoletie pr. n. e.). Sofia.

TRINHGAM R. 1968. A preliminary study of the early Neolithic and latest Mesolithic blade industries in southeast and central Europe. In J. M. Coles, D. D. A. Simpson (eds.), Studies in Ancient Europe.

2000. Southeastern Europe in the transition to agriculture in Europe: bridge, buffer, or mosaic. In T. D. Price (ed.), Europe's First Farmers: 19-56. 
VAJSOV V. 1998. The Typology of the Anthropomorphic Figurines From Norteastern Bulgaria. In M. Stefanovich, H. Todorova, H. Hauptmann (eds.), In The Steps of James Harvey Gaul. Vol. 1: 107-141.

van ANDEL T. H., GALLIS C. and TOUFEXIS G. 1995. Early Neolithic Farming in a Thessalian River Landscape, Greece. In J. Lewin, M. G. Macklin and J. C. Woodward (eds.), Mediterranean Quaternary River Environments: 131-143.

van ANDEL H. T., RUNNELS N. C. 1995. The earliest farmers in Europe. Antiquity 69/264: 481-500.

VOYTEK B. A. and TRINGHAM R. 1990. Rethinking the Mesolithic: the Case of South-East Europe. In C. Bonsall (ed.), The Mesolithic in Europe. Papers Presented at the Third International Symposium Edinburgh 1985: 492-499.

WEINBERG S. 1965. The relative chronology of the Aegean in the stone and early bronze ages. In R. Ehrich (ed.), Chronologies in Old World archaeology: 265-320.

WILLIS K. J. and BENNETT K. D. 1994. The Neolithic transition - fact or fiction? Palaeoecological evidence from the Balkans. The Holocene 4: 326-330.

WILLIS K. 1995. The Pollen-Sedimentological Evidence for the Beginning of Agriculture in South- eastern Europe and Anatolia. Poročilo o raziskovanju paleolita, neolita in eneolita v Sloveniji XXII: 9-24.

ZAMANIS A., SAMARAS S., STAVROPOULOS N. and DILLE J. 1988. Report of an Expedition to Rescue Germplasm of Wild Species of Wheat and Relatives in Greece. Greek Gene Bank Scientific Bulletin. North Greece Agricultural Research Centre.

ZILHÃO J. 1993. The Spread of Agro-Pastoral Economies across Mediterranean Europe: A View from the Far West. Journal of Mediterranean Archaeo$\log y 6 / 1: 5-63$.

1997. Maritime pioneer colonisation in the early Neolithic of the west Mediterranean. Testing the model against the evidence. Porocilo o raziskovanju paleolitika neolitika in eneolitika v Sloveniji XXXIV: 19-42.

ZOHARY D. and HOPF M. 2000. Domestication of Plants in the Old World. Third Edition. Oxford University Press. Oxford.

ZVELEBIL M. 2000. The Social Context of the Agricultural Transition in Europe. In C. Renfrew and K. Boyle (eds.), Archaeogenetics: DNA and the Population prehistory of Europe: 57-79. 